\title{
An instrument to measure organizational culture
}

\author{
W.Z. van der Post, T.J. de Coning \& E.vd M. Smit \\ Graduate School of Business, University of Stellenbosch, P.O. Box 610, Bellville, 7535 Republic of South Africa
}

Received October 1997

\begin{abstract}
Although statistical evidence seems to be lacking, it is at present widely acknowledged that organizational culture has the potential of having a significant effect on organizational performance. An analysis of sustained superior financial performance of certain American organizations has attributed their success to the culture that each of them had developed. It has been proposed that these organizations are characterized by a strong set of core managerial values that define the ways in which they conduct business, how they treat employees, customers, suppliers and others. Culture is to the organization what personality is to the individual. It is a hidden but unifying force that provides meaning and direction and has been defined as the prevailing background fabric of prescriptions and proscriptions for behaviour, the system of beliefs and values and the technology and task of the organization together with the accepted approaches to these. From the literature, a vast number of dimensions of organizational culture were observed. These dimensions were synthetized and 15 constructs of culture emerged. By means of conventional item construction, item analysis and factor analysis, a questionnaire with acceptable reliability and construct validity was developed to measure organizational culture.
\end{abstract}

\section{Introduction}

Already in the 1930s it became evident that workgroups in organizations develop their own unique behavioural norms and that the emergent mode of behaviour could in fact assist or detract from an organization's performance (Roethlisberger \& Dickson, 1975). It was not until the late 1970s that the notion of corporate or organizational culture became the subject of research projects (Davis, 1984; Deal \& Kennedy, 1982; Ouchi, 1981; Schein, 1992; Peters \& Waterman, 1982). Notwithstanding differences in research focus, terminology and methodology, the conclusions were very similar, that is, all firms have corporate cultures, some have stronger cultures than others and these cultures can exert a powerful effect on individuals and on organizational performance (Kotter \& Heskett, 1992: 9).

Although statistical evidence seems to be lacking, it is at present widely acknowledged that corporate culture has the potential of having a significant effect on organizational performance. An analysis of sustained superior financial performance of certain American organizations has attributed their success to the culture that each of them had developed. It has been proposed that these organizations are characterized by a strong set of core managerial values that define the ways in which they conduct business, how they treat employees, customers, suppliers and others (Barney, 1986: 656).

More recent studies indicate that corporate culture can have a significant impact on a firm's long-term financial performance; that corporate culture will probably be an even more important factor in determining the success or failure of firms in the next decade; that corporate cultures that inhibit longterm financial performance are not rare and that they develop easily, even in firms that are staffed by reasonable and intelligent people; and that corporate cultures, although difficult to change, can be made more performance enhancing (Kotter \& Heskett, 1992: 11-12).

\section{Definition of organizational culture}

Culture is to the organization what personality is to the individual. It is a hidden but unifying force that provides meaning and direction (Green, 1989: 72). This organizational personality is referred to as organizational culture that is a system of shared meaning, the prevailing background fabric of prescriptions and proscriptions for behaviour, the system of beliefs and values that ultimately shape employee behaviour.

There is no shortage of definitions of organizational culture. It has been described as the dominant values espoused by an organization (Deal \& Kennedy, 1982), that it constitutes the philosophy that guides an organization's policy towards employees and customers (Pascale \& Athos, 1981), that it is simply the way things are done in an organization (Bower, 1966), and as the basic assumptions and beliefs that are shared by members of an organization (Schein, 1986).

French \& Bell (1984: 18) define culture as the prevailing patterns of values, attitudes, beliefs, assumptions, expectations, activities, interactions, norms, and sentiments in an organization.

White (1991: 17) maintains that the culture of an organization refers to the behaviour patterns and standards that bind it together and that it should not be confused with climate that is the short- term mood of the organization. Culture is the sum of behaviour patterns and is built up over many years.

Quinn (1988: 66-67) defines organizational culture as the set of values and assumptions that underlie the statement, 'This is how we do things around here'. Although cultures tend to vary considerably, they share the common characteristic of providing integration of effort in one direction, while often precluding the possibility of moving into another direction.

Kotter \& Heskett (1992: 4) view organizational culture as having two levels that differ in terms of their visibility and their resistance to change. At the deeper level, culture refers to values that are shared by people in a group and that tends to persist over time. At the more visible level, culture represents the behaviour patterns or style of an organization that new employees are automatically encouraged to follow.

Organizational culture according to Denison (1990:2) refers to the underlying values, beliefs and principles that serve as a foundation for an organization's management system as well as the set of management practices and behaviours that both exemplify and reinforce those basic principles. These principles and practices endure because they have meaning for the members of an organization. 
Schein (1992: 17-21) views organizational culture as consisting of three elements. The most clearly visible level of culture is its artifacts and creations, that is, the technological output of the organization, its written and spoken language and the overt behaviour of its members. Culture at this level is visible, but not always decipherable. At a deeper level, Schein identifies values or a sense of what ought to be. Values gradually start a process of cognitive transformation into beliefs and ultimately assumptions that are found at an even deeper level of consciousness. If the espoused values are reasonably congruent with the underlying assumptions, then the articulation of those values into a philosophy of operating can be helpful in bringing the group together, serving as a source of identity and core mission.

Schein (1990: 109-119) earlier defined organizational culture as a pattern of basic assumptions invented, discovered or developed by a given group as it learns to cope with its problems of external adaptation and internal integration that has worked well enough to be considered valid and therefore is to be taught to new members as the correct way to think and feel in relation to those problems.

Culture is the commonly held and relatively stable beliefs, attitudes and values that exist within an organization (Williams, Dobson \& Walters, 1990: 11).

There are patterns of beliefs, symbols, rituals, myths and practices that have evolved over time in every organization. Together these constitute the culture. It is, however, not simply another variable or isolatable component of organizations. It is what organizations are (Smircich, 1983: 347).

Organizational culture creates common understandings among members about what the organization is and how its members should behave.

'Organisation culture is how things are done around here. It is what is typical of the organisation, the habits, the prevailing attitudes, the grown-up pattern of accepted and expected behaviour' (Drenan, 1992: 3).

Organizational culture is the patterned way of thinking, feeling and reacting that exists in an organization or its subsectors (Tosi, Rizzo \& Carrol, 1990: 117).

Ott (1989: 69) defines organizational culture as a social force that controls patterns of organizational behaviour by shaping members' cognitions and perceptions of meanings and realities, providing affective energy for mobilization, and identifying who belongs and who does not.

All these definitions, however, have a central theme, namely that organizational culture refers to a system of shared meaning, the prevailing background fabric of prescriptions and proscriptions for behaviour, the system of beliefs and values and the technology and task of the organization together with the accepted approaches to these.

\section{Dimensions of organizational culture}

At the overt level, culture implies the existence of certain dimensions or characteristics that are closely associated and interdependent. Generally, however, research on organizational culture does not specify a set of uniform dimensions or characteristics. From the liter ature, 114 dimensions of organizational culture have been identified.
Harrison (1972: 121-123) created a culture framework which provides for four different cultural orientations in organizations. This framework may be summarized as follows:

- Power orientation: the desire to dominate the environment and vanquish all opposition, organizational life being principally governed by the use of power and politics.

- Role orientation: the desire to be as rational and orderly as possible, organizational life being governed principally by considerations of rights, privileges, legality and legitimacy.

- Task orientation: the desire to get the job done and achieve results, organizational life being dictated mainly by what would facilitate task accomplishment.

- Person orientation: the desire to serve the needs of the organization's members, organizational life being principally guided by considerations of what would best satisfy the members' needs.

Likert (1967: 197-211), in his System 4 management approach identified nine organizational variables, namely, leadership, motivational forces, communication processes, interaction processes, decision-making processes, goal-setting processes, control processes, performance expectations and training.

Litwin \& Stringer (1968: 81-82) identified the nine organizational climate measures, namely, structure, responsibility, reward, risk, warmth, support, standards, conflict and identity.

Gordon \& Cummins (1979: 29) identified eight measures of organizational culture, namely, organizational clarity, decision making, organizational integration, management style, performance orientation, organizational vitality, compensation and human resource development.

Gordon (1988: 106) identified eleven organization culture dimensions, namely, clarity of direction, organizational reach, integration, top management contact, encouragement of individual initiative, conflict resolution, performance clarity, performance emphasis, action orientation, compensation and human resource development.

Peters \& Waterman (1982: 13-15) identified eight characteristics of excellent organizations namely, a bias for action, closeness to the customer, autonomous and entrepreneurial leadership, productivity through people, strongly managed value systems, knowing their businesses, simple organization structures and decentralized authority.

The Hewlett-Packard company identified ten cultural dimensions, namely, customer orientation, workmanship, familial atmosphere, employee importance, inter-organizational co-operation, entrepreneurial spirit, management style, pride in Hewlett-Packard, social neighbour attitude and profit (Fombrun, Tichy \& Devanna, 1984: 220).

Robbins (1990:439) suggested ten dimensions along which culture could be measured, namely, individual initiative, risk tolerance, direction, integration, management support, control, identity, reward system, conflict tolerance, communication patterns.

Rossiter (1989:15) suggested five dimensions namely, delegation of authority, teamwork across boundaries, empowerment of employees to contribute to results, integration of employees with technology and finally a shared sense of purpose. 
Bettinger (1989: 38-42) identified twelve dimensions of organization culture, namely, attitude towards change, strategic organization focus on goals and objectives, performance standards and values that contribute towards success, rituals to support and reinforce values, concern for people, rewards and punishments that positively reinforce behaviour, openness in communication and supervision, conflict resolution aimed at minimizing dysfunctional results, market and customer orientation, a sense of pride in the mission and objectives of the organization, commitment to the organization and teamwork.

Allen \& Dyer (1980: 194-197) identified seven scales along which culture may be measured, namely, performance facilitation, job involvement, training, leader-subordinate interaction, policies and procedures, confrontation and a supportive climate.

Denison (1990:43-45) applied 21 measures of organizational culture namely, organization of work, communication flow, emphasis on people, decision-making practices, influence and control, absence of bureaucracy, co-ordination, job challenge, job reward, job clarity, supervisory support, supervisory team building, supervisory goal emphasis, supervisory work facilitation, peer support, peer team building, peer goal emphasis, peer work facilitation, group functioning, satisfaction, goal integration.

From the above, it is evident that various researchers have applied a large number of dimensions of organization culture that cannot be neatly categorized in terms of an overall organizational culture theory. All the dimensions observed, together with a brief operational definition of each of them have been summarized in Appendix 1.

\section{A synthesis of dimensions identified}

One hundred and fourteen dimensions of organizational culture were identified in the literature review. Individually these dimensions were found not to be unique due to the fact that many of them, to some extent, overlapped. To develop an instrument by means of which organizational culture may be measured, it was necessary to distil from the 114 dimensions a set of unique dimensions.

To synthesize the dimensions identified, a panel consisting of human resource experts was requested to compare all the dimensions with each other and to group them into logical categories. The process followed entailed two steps.

In step one, all the dimensions with their definitions were recorded on cards, that is one dimension per card. The panellists each received a set of these cards with the request to individually classify all the dimensions into categories on the basis of similarity. At the end of step one, the panel members had each created between 12 and 19 categories into which all the dimensions were classified.

In step two, the results of step one were fed back to the panel as a group with the request that they jointly discuss their respective categorization of the dimensions with a view to reach consensus on those dimensions not already similarly categorized. This required a review of the categories already created as well as a reclassification of the dimensions. At the end of step two which required several sessions of discussion, fifteen dimensions of culture emerged. They may be labelled and described as follows.

\section{Conflict resolution}

The degree to which the organization is perceived to encourage employees to air conflicts and criticisms openly. Do subordinates perceive a willingness by superiors to hear different opinions? Is there an emphasis on getting problems out in the open as opposed to smoothing them over or ignoring them?

\section{Culture management}

The extent to which the organization is actively and deliberately engaged in shaping the organization's culture. Are there expressive events, ceremonies or rituals that are designed specifically to reinforce in a powerful and incontrovertible way the organization's values and philosophies? Are there an understanding and belief in those core values and performance standards? Do employees understand and share a vision which unites the energies of the organization's membership?

\section{Customer orientation}

The extent to which the organization takes the views of customers seriously and actively responds to such views. Do employees perceive that emphasis is placed by everyone in the organization on quality, service and reliability of products and services? Is there a willingness to listen to customers, to find out what they want and any ideas they may have for product improvement?

\section{Disposition towards change}

The degree to which employees are encouraged to be creative and innovative and to constantly search for better ways of getting the job done. Are employees in all parts of the organization encouraged to experiment and to take practical risks? Are mistakes viewed as a natural occurrence in an innovative environment or are employees punished when their solutions to problems are imperfect? Is there a strong emphasis on experimentation or are employees expected to follow the book in dealing with business problems? Is there an emphasis on individual initiative?

\section{Employee participation}

The extent to which employees perceive themselves as participating in the decision-making process of the organization. Are employees involved in making decisions which directly influence their work? Do they participate in setting individual and group goals? Do they have a say in broader policy matters?

\section{Goal clarity}

The degree to which the organization creates clear objectives and performance expectations. Are employees clearly informed as to the plans and objectives of the organization to understand their particular roles? Do they understand the mission, objectives and values of the organization to the extent that they are prompted to work together as teams and to care about the quantity and quality of the organization's outputs? 


\section{Human resource orientation}

The extent to which the organization is perceived as having a high regard for its human resources. Does the organization view its employees as a valued resource and an important contributor to its success? Are rank and file employees seen as a key source of ideas for improvements in quality and productivity? Do employees perceive a commitment towards the development and training of the organization's human resources? Do they experience systematic training and development interventions aimed at assisting them to develop to their full potential?

\section{Identification with the organization}

The degree to which employees are encouraged to identify with the organization. Does the organization create opportunities for employees to socialize and to extend business friendships away from their work? Do employees experience an emotional involvement in their jobs and in the organization? Do employees share a high degree of commitment to make the organization's strategic vision a reality?

\section{Locus of authority}

The degree of responsibility, freedom and independence individual employees have. Is authority located mostly at the top of the organization or is it in the hands of people actually doing the work? Is the management of the organization centralized or decentralized? Are employees empowered to make appropriate decisions or do they have to refer these up the line? Do they have a perception of being able to manage and get on with the job or do they have to double-check all their decisions?

\section{Management style}

The degree to which managers provide clear communication, assistance and support to their subordinates. Do employees generally perceive higher levels of management to be helpful and supportive when needed or is it a case of 'sink or swim'? Do employees have confidence and trust in their supervisors? Is communication perceived to flow freely, accurately and undisturbed throughout the organization upwards, downwards and laterally? Do employees feel that they have the information they need to do their jobs well?

\section{Organization focus}

The extent to which the organization is perceived to be concentrating on those activities which form part of the fundamentals of the business. Does the organization involve itself in activities which are peripheral to the fundamental business process or does it restrict itself to what it knows and does well?

\section{Organization integration}

The degree to which various subunits within the organization are actively encouraged to operate in a co-ordinated way by co-operating effectively towards the achievement of overall organizational objectives. Are employees encouraged to work in interdisciplinary teams across departmental boundaries to provide input into the design and delivery of the product or service to the customer? Is there a spirit among employees which causes them to share information and support each other across departmental or work group boundaries? Are employees encouraged to work with one another for the good of the organization or is each unit or department working in isolation and often in conflict with one another?

\section{Performance orientation}

The extent to which emphasis is placed on individual accountability for clearly defined results and a high level of performance. Is it perceived as important to have clear goals and performance standards? Do employees perceive an emphasis on doing a good job? Do employees perceive individual and collective goals to be demanding and actively sought by supervisors? Do employees perceive a clear organizational norm to maintain progress and strive towards excellence?

\section{Reward orientation}

The degree to which reward allocations are based on employee performance in contrast to seniority or favouritism. Do employees perceive a linkage between reward and performance or is reward dependant on service, seniority, qualifications or other non-performance related factors? Do employees perceive the organization to place emphasis on positively reinforcing behaviour which supports the organization's objectives as opposed to focussing on negatively punishing behaviour that does not support the organization's objectives? Do employees perceive the organization's reward system as reinforcing the notion that most employees are good performers or that most employees are not good performers?

\section{Task structure}

The degree to which rules and regulations and direct supervision are applied to manage employee behaviour. Do employees perceive the execution of their duties to be governed by rules, regulations, policies, procedures, working through channels or do they perceive a loose and informal atmosphere which allows them to be creative and innovative in pursuing the achievement of organizational objectives?

The constructs underlying each of the fifteen dimensions of culture have been summarized in Tablel. These constructs were utilized as the basis on which questionnaire items were produced for the preliminary questionnaire.

\section{Creation of an item pool and the preliminary ques- tionnaire}

The first step towards the development of a questionnaire by means of which each of the culture dimensions could be measured, was to develop a pool of items. In creating the item pool the standard set of rules for item writing was observed (Oppenheim, 1992: 128-130). Approximately half the items were written as positive statements with the other half as negative statements (Kline, 1986: 111-112).

A total of 225 items were produced, that is 15 items per dimension. These items were then given to a panel of human resource managers for inspection and evaluation to ensure that the items were clear, that no overlaps occurred and that items were not repeated (Smit, 1991: 155). This evaluation resulted in a total of 169 items being retained in the preliminary questionnaire. There were between nine and 15 items per 


\begin{tabular}{|c|c|}
\hline $\begin{array}{l}\text { Conflict } \\
\text { resolution }\end{array}$ & $\begin{array}{l}\text { The degree to which the organization is perceived to en- } \\
\text { courage employees to air conflicts and criticisms openly }\end{array}$ \\
\hline $\begin{array}{l}\text { Culture } \\
\text { management }\end{array}$ & $\begin{array}{l}\text { The extent to which the organization actively and } \\
\text { delibera-tely engages in shaping the organization's } \\
\text { culture }\end{array}$ \\
\hline $\begin{array}{l}\text { Customer } \\
\text { orientation }\end{array}$ & $\begin{array}{l}\text { The extent to which the organization takes the views of } \\
\text { cus-tomers seriously and actively responds to such views }\end{array}$ \\
\hline $\begin{array}{l}\text { Disposition } \\
\text { towards } \\
\text { change }\end{array}$ & $\begin{array}{l}\text { The degree to which employees are encouraged to be } \\
\text { creative and innovative and to constantly search for better } \\
\text { ways of getting the job done }\end{array}$ \\
\hline $\begin{array}{l}\text { Employee } \\
\text { participation }\end{array}$ & $\begin{array}{l}\text { The extent to which employees perceive themselves as } \\
\text { participating in the decision-making process of the } \\
\text { organization }\end{array}$ \\
\hline $\begin{array}{l}\text { Goal } \\
\text { clarity }\end{array}$ & $\begin{array}{l}\text { The degree to which the organization creates clear } \\
\text { objectives and performance expectations }\end{array}$ \\
\hline
\end{tabular}

Human resource The extent to which the organization is perceived as orientation having a high regard for its human resources

Identification with The degree to which employees are encouraged to the organization idintify with the organization

Locus of The degree of authority, freedom and independence that
authority
individual employees have in their jobs

style authority

Management

Organization

focus

Organization

integration

Performance

orientation

Reward

orientation

Task

structure

The degree to which managers provide clear communication, assistance and support to their subordinates

The extent to which the organization is perceived to be concentrating on those activities which form part of the fundamentals of the business

The degree to which various subunits within the organization are actively encouraged to operate in a co-ordinated way by co-operating effectively towards the achievement of overall organizational objectives

The extent to which emphasis is placed on individual accountability for clearly defined results and a high level of performance

The degree to which reward allocations are based on employee performance in contrast to seniority, favouritism or any other non-performance criterion.

The degree to which rules and regulations and direct supervision are applied to manage employee behaviour

dimension. The number of items per dimension satisfied the requirement that approximately one and half times as many items should be included as are planned for the final questionnaire (Smit, 1991: 155). These items were then randomly reorganized into a preliminary Likert-type questionnaire that consisted of a seven-point scale. Nunnally (1978: 595) maintains that reliability increases with the number of scale points but tends to level off at about seven points. By so doing a balance was struck between reliability on the one hand and practical common sense on the other which dictates that a large number of scale points would cause respondents difficulty in making up their minds about which point to select. Nunnally (1978: 595) maintains that a graphic scale with numbers is preferred. To this end the questionnaire was constructed as depicted in Figure 1.

The questionnaire was scored as follows. For positive statements the actual scale numbers marked by the respondents were taken. For negative statements the scores were computed as the scale steps plus one $(7+1)$ minus the actual scale number selected by respondents (Kline, 1986: 115). The respondent's total score on a dimension was arrived at by summing the scores obtained in this way on all the items. It should be noted that the data thus obtained may be treated as interval level measurements (Scott \& Wertheimer, 1967: 122).

\section{Selection of items and reliability}

By means of item analysis it is possible to shorten a test and at the same time to increase its reliability (Anastasi, 1982: 192).

The preliminary questionnaire containing 169 items was administered to a group of persons employed at the management, supervisory and worker level. Filve hundred questionnaires were handed to persons in eight different organizations. It was explained to them that the exercise was anonymous and for research purposes only, and that their respective organizations were not being evaluated. Four hundred and eight questionnaires were returned. The return rate, therefore, was $81.6 \%$.

An item analysis as described by Nunnally (1978: 605) was carried out on the scores obtained from this questionnaire with the objective of selecting the best items and determining reliability.

Nunnally (1978: 279) argues that items that correlate highly with total scores are the best items for a test. The product-moment coefficient would be the appropriate measure in the case of multi-point items. However, where the Pearson productmoment correlation is computed for an item analysis, account must be taken of the fact that the item is part of the total test score. This causes the correlation of the item with the total test scores to be higher than if the item is correlated with scores on all the other items. This spurious source of the itemtotal correlation can, however, be removed with the following formula (Nunnally, 1978: 281):

$$
r_{i(y-i)}=\frac{r_{y i} \sigma_{y} \sigma_{i}}{\sqrt{\sigma_{i}^{2}+\sigma_{y}^{2}-2 \sigma_{i} \sigma_{y} r_{y i}}}
$$

where:

$r_{y i}=$ correlation of item i with total score;

$\sigma_{y}=$ standard deviation of total score;

$\sigma_{i}=$ standard deviation of item $\mathrm{i}$; and

\begin{tabular}{|l|c|c|c|c|c|c|c|}
\cline { 2 - 7 } \multicolumn{1}{c|}{} & $\begin{array}{c}\text { Completely } \\
\text { disagree }\end{array}$ & $\begin{array}{c}\text { Mostly } \\
\text { disagree }\end{array}$ & $\begin{array}{c}\text { Slightly } \\
\text { disagree }\end{array}$ & $\begin{array}{c}\text { Un- } \\
\text { decided }\end{array}$ & $\begin{array}{c}\text { Slightly } \\
\text { agree }\end{array}$ & $\begin{array}{c}\text { Mostly } \\
\text { agree }\end{array}$ & $\begin{array}{c}\text { Completely } \\
\text { agree }\end{array}$ \\
\hline & 1 & 2 & 3 & 4 & 5 & 6 & 7 \\
\hline $\begin{array}{l}\text { Managers in this organization } \\
\text { really care about employees }\end{array}$ & & & & & & & \\
\hline
\end{tabular}

Figure 1 Item form of the questionnaire 
$r_{i(y-i)}=$ correlation of item $i$ with sum of scores on all items exclusive of item $\mathrm{i}$.

Items with the highest correlation coefficients with the total score should be included in the test because when combined, they form a scale with highest internal consistency (Hulin. Drasgow \& Parsons, 1983: 77). An important index of internal consistency is Cronbach's (1951) coefficient alpha. It is computed as follows:

$$
\text { Coefficient } \alpha=\frac{n}{n-1} \quad\left[1-\frac{\Sigma \sigma^{2} l}{\sigma^{2}}\right]
$$

where:

$\mathbf{n}=$ number of items in the scale;

$\square \square \Sigma \sigma_{1}^{2}=$ sum of the item variances; and

$\sigma_{x}^{2}=$ variance of the total test scores.

This coefficient provides the researcher with a measure of item homogeneity or internal consistency that algebraically equals the average of the split-half coefficients as computed by means of the Guttman formula on all possible splits of a test (Huysamen, 1980: 66). As a measure of test reliability coefficient alpha may be used with dichotomous as well as multi-point items and equals the Kuder-Richardson formula20 (Huysamen, 1990: 30-31).

Kline (1986: 124) maintains that there can be no doubt that coefficient alpha is the most efficient measure of reliability and should always be computed. According to Nunnally (1978: 278) it is not unusual to find a coefficient alpha of 0.80 for ten agree-disagree attitude statements on a seven-point scale. Reliability should always be $>0.7$ when items are selected for a test (Kline, 1986: 144).

The preliminary questionnaire containing 169 items required approximately 30 minutes for completion. This was considered too long because respondents may be more willing to complete the questionnaire if less time was required. In constructing the final questionnaire it was felt that fewer items requiring approximately fifteen minutes for completion would be more appropriate and, therefore, the aim was to select between 90 and 110 items provided an acceptable reliability as measured by coefficient alpha could be maintained. Table 2 summarizes the results of the item analysis.

It is evident from Table 2 that the number of items retained in the final questionnaire total 97 , that is $57 \%$ of the original number of items. The reliability coefficients for each of the culture dimensions vary between 0.788 and 0.932 .

\section{Validity}

The major purpose of item analysis is the determination of the degree to which items can discriminate among individuals in terms of some criterion. This criterion is usually the total score on the preliminary form and items that correlate well with the criterion, whether an external criterion or the total score are retained as good items and those with poor correlations are rejected (Guion, 1965: 203). In this study it was clearly not possible to employ an external criterion in terms of which the validity of the items may be determined. According to Magnussen (1966: 130), the notion of construct validity is useful with reference to tests measuring traits for which external criteria are not available. Guion defines construct validity as the degree to which the variance in a given set of measures is due to variance in the underlying construct. The factors derived from factor analysis are constructs and the operational definition of construct validity is a factor loading. This permits a specific numerical statement of construct validity that is important for both criterion and predictor measurement (Guion, 1965: 128-129). By means of factor analysis it is possible to construct a test giving a relatively pure measurement of a specific theoretical construct. This is achieved by a factor analysis of the items in the test that individually are considered as variables. It is the analysis of the internal statistical structure of these variables culminating in a factor loading which provides the researcher with a measure of a specific construct (Smit, 1991: 74).

Following the item analysis, the data relating to the retained 97 items were factor analysed. A principal factor analysis

\begin{tabular}{llc}
\hline \multicolumn{2}{l}{ Table 2 Results of the item analysis } & \\
\hline Organizational culture dimension & \multicolumn{1}{l}{ Items selected } & Coefficient alpha \\
\hline Conflict resolution & $20,75,79,126,127,161,164$ & 0.875 \\
Culture management & $47,49,78,85,119,169$ & 0.828 \\
Customer orientation & $40,82,87,121,148$ & 0.874 \\
Disposition towards change & $18,23,68,107,120$ & 0.855 \\
Employee participation & $16,66,100,122,144,146,157$ & 0.881 \\
Goal clarity & $30,63,74,83,89,103,110$ & 0.932 \\
Human resources orientation & $48,54,56,71,167$ & 0.858 \\
Identification with organization & $5,36,37,98,115,141,160$ & 0.907 \\
Locus of authority & $62,67,93,104,134,162$ & 0.884 \\
Management style & $84,94,102,114,128,149$ & 0.819 \\
Organization focus & $22,24,95,147,150,151,154$ & 0.818 \\
Organization integration & $25,28,41,97,130,138$ & 0.788 \\
Performance orientation & $43,46,123,125,142,143,152$ & 0.907 \\
Reward orientation & $9,55,60,65,80,136,153$ & 0.896 \\
Task structure & $32,61,76,77,101,105,106,132,139$ & 0.890 \\
\hline
\end{tabular}


with an orthogonal varimax rotation yielded the rotated factor pattern as detailed in Appendix 2. Fifteen factors with eigen values $>1.0$ were identified. It is evident from Appendix 2 that high to moderate factor loadings on each factor were obtained, that is between 0.8408 and 0.3916 that suggests an acceptable level of construct validity. The factors that emerged are identical in structure to the constructs identified in Table 1. The factor labels in Table 3 summarize the relationship between each of the organizational culture dimensions and the factors that emerged.

The items selected were randomly reordered for inclusion in the final questionnaire that may be found in Appendix 3 . The key to the questionnaire items in respect of the cultural dimensions to which they relate may be found in Appendix 4.

\section{Conclusion}

Research on organizational culture has been characterized by the application of a large number of dimensions defining culture. Furthermore, these dimensions cannot be neatly categorized in cerms of an overall organizational culture theory. This article described an attempt to synthesize those dimensions identified by means of a literature review as well as the development of a questionnaire with acceptable reliability and construct validity to measure organizational culture.

Given the fact that it is today widely acknowledged that organizational culture has a significant impact on long-term financial performance, the questionnaire developed may usefully be applied where the measurement of a particular organization's culture is required.

\section{References}

Allen, R.F. \& Dyer, F.J. 1980. A tool for tapping the organisational unconscious, Personnel Journal, March: 57-63.

Anastasi, Anne. 1982. Psychological testing. New York: MacMillan. 784 p.

Barney, J.B. 1986. Organisational culture: can it be a source of sustained competitive advantage? Academy of Management Review, 11(3): 656-665.

\begin{tabular}{ll}
\hline Table 3 & Factor labels of the factors \\
emerging & from the factor analysis \\
\hline Factor 1 & Goal clarity \\
Factor 2 & Task structure \\
Factor 3 & Identification with organization \\
Factor 4 & Performance orientation \\
Factor 5 & Conflict resolution \\
Factor 6 & Reward orientation \\
Factor 7 & Employee participation \\
Factor 8 & Locus of authority \\
Factor 9 & Organizational focus \\
Factor 10 & Culture management \\
Factor 11 & Customer orientation \\
Factor 12 & Disposition towards change \\
Factor 13 & Human resource orientation \\
Factor 14 & Management style \\
Factor 15 & Organization integration \\
\hline
\end{tabular}

Bettinger, C. 1989. Use corporate culture to trigger high performance, Journal of Business Strategy, March-April: 38-42.

Bower, M. 1966. The will to manage. New York: McGraw-Hill, 276p.

Cronbach, 1951. Coefficient alpha and the internal structure of tests, Psychometrika, 16(3): 297--334.

Davis, S. 1984. Managing corporate culture. Cambridge, Massachusetts: Balinger, 123p.

Deal, T.E. \& Kennedy, A.A. 1982. Corporate cultures: the rites and rules of corporate life. Reading. Massachusetts: Addison-Wesley, 232p.

Denison, D.R. 1990. Corporate culture and organisation effectiveness. New York: John Wiley. 267p.

Drennan, D. 1992. Transforming company culture. London: McGraw-Hill, 299p.

Fombrun, C.J., Tichy, N.M. \& Devanna, M.A. 1984. Strategic human resources management. New York: John Wiley, 499p.

French, W.L. \& Bell, C.H. 1984. Organisation development. Englewood Cliffs, New Jersey: Prentice-Hall, 247p.

Gordon, G.G. 1988. The relationship of corporate culture to industry sector and corporate performance. In Kilmann, R.H., Saxton, M.J., Serpa, R. \& Associates. Gaining control of the corporate culture. San Francisco: Jossey-Bass, 45Ip.

Gordon, G.G. \& Cummins. W.M. 1979. Managing management climate. Lexington: Massachusetts: L.exington books, 184p.

Green, L. 1989. Corporate culture: asset or liability. Human Resources Management Yearbook, 72. 74.

Guion, R.M. 1965. Personnel testing. New York: McGraw-Hill, 585p.

Harrison, R. 1972. Understanding your organisation's character, Harvard Business Review, May- June: 119-128.

Hulin, C.L., Drasgow, F. \& Parsons, C.K. 1983. Item response theory. Application to psychological measurement. Homewood Illinois: Dow-Jones-Irwin, 302p.

Huysamen, G.K. 1980. Beginsels van sielkundige meting. Pretoria: Academia, 212p

Huysamen, G.K. 1990. Sielkundige meting. Pretoria: Academia. $124 \mathrm{p}$.

Kline, P. 1986. A handbook of test construction. New York: Methuen and Company. 259p.

Kotter, J.P. \& Heskett. J.L. 1992. Corporate culture and performance. New York: The Free Press. 214p.

Likert, R. 1967. The human organisation. New York: McGraw-Hill, 258p.

Litwin, G.H. \& Stringer. R.A. 1968. Motivation and organisational climate. Boston: Harvard University. 213p.

Magnussen, D. 1966. Test theor: Reading. Massachusetts: AddisonWesley, 270p.

Nunnaly, J.C. 1978. Psychometric theory: New York: McGraw-Hill. $701 \mathrm{p}$.

Oppenheim, 1992. Questionnaire design, interviewing and attitude measurement. London: Pinter Publishers, 303p.

Ott, J.S. 1989. The organisation culture perspective. Pacific Grove: Brooks-Cole, 23lp.

Ouchi, W.G. 1981. Theory Z. Reading, Massachusetts: AddisonWesley, 244p.

Pascale, R.T. \& Athos, A.G. 1981. The art of Japanese management. New York: Simon and Schuster, 221p.

Peters, T.J. \& Waterman, R.H. 1982. In search of excellence. Lessons from America's best run companies. New York: Harper and Row, $360 \mathrm{p}$.

Quinn, R.E. 1988. Beyond rational management. San Francisco: Jossey-Bass, $199 \mathrm{p}$.

Robbins, S.P. 1990. Organisation theory. Structure design and applications. New Jersey: Prentice Hall. 552p.

Roethlisberger, F.J. \& Dickson. W.J. 1975. Management and the 
worker. An account of a research programme conducted by Western Electric Company, Hawthorne Works Chicago. Cambridge: Harvard University Press, 613p.

Rossiter, M. 1989. Using corporate culture to build winning organisations, Institute of Personnel Management Journal, April, 14-15.

Schein, E.H. 1990. Organisation culture, American Psychologist, 45 (2): 109-119.

Schein, E.H. 1992. Organisational culture and leadership. San Francisco: Jossey-Bass, 418p.

Scott, W.A. \& Wertheimer, M. 1967. Introduction to psychological research. New York: John Wiley, 445p.

Smircich, L. 1983. Concepts of culture and organisation analysis, Administrative Science Quarterly, September: 339-358.

Smit, G.J. 1991. Psigometrika Aspekte van toetsgebruik. Pretoria: HAUM, 449p.

Tosi, H.L., Rizzo, J.R. \& Carrol, S.J. 1990. Managing organisational behaviour. New York: Harper Collins, 805p.

White. J. 1991. Corporate culture and corporate success, South African Handbook of Management Development, 6.6: 17-22.

Williams, A., Dobson, P. \& Walters, M. 1990. Changing culture. London: Institute of Personnel Management, 230p.

\section{Appendix 1}

Organizational culture dimensions observed in the literature

Absence of bureaucracy

The absence of unnecessary administrative constraints in the organization's internal functioning.

\section{A bias for action}

A strong emphasis upon experimentation. People are encouraged to try out new ideas and approaches and are not punished if their initial solutions to problems were imperfect. This emphasis on taking action in response to problems contributes to a high degree of vitality and innovation.

\section{Action orientation}

The extent to which the timeliness with which decisions are made, a sense of urgency to get things done, and a responsiveness to changes in the marketplace is emphasized.

\section{Autonomy and entrepreneurship.}

Significant emphasis placed on the encouragement of leadership and innovation throughout the organization. New ideas and new products are not the sole responsibility of a single specialized 'research and development' department. People in all parts of the organization are encouraged to be creative, to experiment, and to take practical risks. Mistakes are viewed as a natural occurrence in an innovative environment.

\section{Attitude towards change}

The extent to which there is a positive leadership attitude towards change to constantly search for better ways of getting the job done.

\section{A shared sense of purpose}

The extent to which the sharing of a vision unites the energies of the membership of the organization.

\section{Clarity of direction}

The extent to which the company emphasizes creating clear objectives and plans to meet them.

\section{Control}

The number of rules and regulations, and the amount of direct supervision that are used to oversee and control employee behaviour.

\section{Conflict tolerance}

The degree to which employees are encouraged to air conflicts and criticisms openly.

\section{Communication patterns}

The degree to which organizational communications are restricted to the formal hierarchy of authority.

\section{Compensation}

The extent to which the compensation system is seen as equitable, competitive, and related to performance.

\section{Closeness to the customer}

Tremendous emphasis placed by everyone in the organization on quality, service, and the reliability of products and services. A willingness to listen to customers, to find out what they want and what ideas customers may have for product improvement.

\section{Conflict}

The feeling that managers and other workers want to hear different opinions; the emphasis placed on getting problems out in the open, rather than smoothing them over or ignoring them.

\section{Communication process}

The extent to which information flows freely throughout the organization upwards, downwards and laterally. The information is accurate and undistorted.

\section{Control process}

The extent to which this process is dispersed throughout the organization and emphasizes self-control and problem solving.

\section{Confrontation}

The extent to which the organization encourages constructive responses to employee behaviour, that is, interaction where unconscious material is brought into the employee's field of awareness in such a way as to have a therapeutic effect.

\section{Conflict resolution}

The extent to which there is a conflict resolution style which focusses on a 'us versus you' perspective. The conflict is analysed in terms of the needs and objectives of the organization and not in terms of ego needs of the individuals involved.

\section{Commitment}

The extent to which there is a high degree of commitment from all employees to make the organization's strategic vision a reality.

\section{Concern for people}

The extent to which employees view the organization as sincerely caring abouttheir interests

\section{Communication flow}

The flow of information, both vertically within the organizational hierarchy and laterally across the organization.

\section{Co-ordination}

Co-ordination, co-operation, and problem resolution among organizational units. 


\section{Conflict resolution}

The extent to which employees are encouraged to air conflicts and criticisms openly.

\section{Compensation}

The extent to which employees perceive the company as paying competitively and fairly as well as relating that pay to performance.

\section{Direction}

The degree to which the organization creates clear objectives and performance expectations

\section{Decision-making}

The extent to which decisions are made in a rational manner, effectively implemented, and systematically evaluated in terms of their effects

\section{Decentralized authority}

The management of the organization is decentralized in the sense that authority and responsibility tend to be pushed down in the organization to the people actually doing the work. There is a high degree of autonomy and a great deal of emphasis on individual initiative.

\section{Delegation}

The extent to which authority in control is extended to the people actually doing the work.

\section{Decision-making practices}

The degree to which an organization's decisions involve those who will be affected, are made at appropriate levels, and are based on widely shared information.

\section{Decision-making process}

The extent to which decisions are made at all levels through group processes

\section{Excitement, pride and esprit de corps}

The extent to which there is a tangible spirit of excitement and pride that causes employees to understand and believe in the mission, objectives and values of the organization which in turn prompts them to work together as a team, to care about each other and the quality and quantity of their work

\section{Empowering people}

The extent to which opportunities for everyone to contribute to the performance objectives of the organization is provided.

\section{Emphasis on people}

The interest that the organization displays in the welfare and development of the people who work there.

\section{Encouragement of individual initiative}

The extent to which freedom to act, innovation, and risk taking is emphasized.

\section{Goal integration}

The compatibility of individual and organizational needs

\section{Group functioning}

Group members' planning, and co-ordination, decision making and problem solving, knowledge of jobs, trust, and sharing of information.

\section{Goal-setting process}

The extent to which this process encourages group participation in setting high, realistic objectives.

\section{Human resource development}

The extent to which companies provide upportunities for employees to grow and develop within the company.

\section{Human resource development}

The extent to which individuals perceive opportunities within the organization to develop to their full potential.

Influence and control

The influence of those at the lower levels of the organization.

\section{Integration}

The extent to which units are encouraged to operate in a coordinated manner. This is an indicator of horizontal interdependence

Individual initiative

The degree of responsibility, freedom, and independence that individuals have.

\section{Integration}

The degree to which units within the organization are encouraged to operate in acoordinated manner.

\section{Identity}

The degree to which members identify with the organization as a whole rather than with their particular work group or field of professional expertise.

Identity

The feeling that you belong to a company and you are a valuable member of a working team; the importance placed on this kind of spirit.

\section{Interaction process}

The extent to which interaction is open and extensive; both superiors and subordinates are able to affect departmental goals, methods. and activities.

\section{Job involvement}

The extent of employees' emotional involvement in their jobs and in the total organization.

\section{Job challenge}

Variety, opportunity to learn, and the use of skills and abilities on the job.

\section{Job reward}

Instrumentality of good job performance with regard to recognition. respect, and getting ahead.

Job clarity

Clear and appropriate job expectations.

\section{Leadership process}

The extent to which there is confidence and trust between superiors and subordinates in all matters. 


\section{Leader-subordinate interaction}

The extent to which leaders in the organization are concerned about their subordinates as people, take time to perform adequate followup, and are receptive to upward communication.

\section{Management support}

The degree to which managers provide clear communication, assistance, and support to their subordinates.

\section{Management style}

The extent to which people perceive encouragement to use their own initiative in performing their jobs, feel free to question constraints, and sense support when needed from higher levels of management.

\section{Motivational process}

The extent to which the process taps a full range of motives.

\section{Market and customer orientation}

The extent to which the organization takes the views of the market or customer seriously and actively responds to such views.

Organizational clarity

The degree to which the goals and plans of the organization are clearly perceived by its members.

\section{Organization integration}

The extent to which various subunits co-operate and communicate effectively towards the achievement of overall organizational objectives.

\section{Organizational vitality}

The extent to which people see the organization as a dynamic one, as reflected by the venturesomeness of its goals, the imaginativeness of its decisions, and its responsiveness to changing conditions.

\section{Openness in communication and supervision}

The extent to which internal and external communication is thought of as strategic because its purpose is to bring about the realization of organizational objectives.

\section{Organization of work}

The degree to which an organization's work methods link the jobs of individuals to organizational objectives.

\section{Organizational reach}

The extent to which the company sets venturesome goals and approaches its business in an innovative way.

\section{Performance orientation}

The extent to which emphasis is placed upon individual accountability for clearly defined results and high levels of performance.

\section{Personal freedom}

Self-expression, exercising discretion, and pleasing oneself, such as: 'Live for yourself and your family' versus 'Live for your job and career'.

\section{Productivity through people}

The organization views every one of its members from the bottom up as a valued resource and an important contributor to the company's success. Rank and file members are seen as a key source of ideas for improvements in quality and productivity.

\section{Performance goals}

The extent to which goals are demanding and actively sought by superiors, who recognize the necessity for making a full commitment to developing, through training, the human resources of the organization.

\section{People integrated with technology}

The extent to which there is a move away from people in service of technology and towards people controlling the technology.

\section{Performance facilitation}

A performance facilitating norm, that is the extent to which employees perceive a norm to maintain progress and to strive towards excellence.

\section{Policies and procedures}

The efficiency of organizational policies and procedures and the extent to which they are effectively communicated to those who must implement them.

\section{Peer support}

Peers' attentiveness, approachability, and willingness to listen.

Peer team building

Peers' emphasis of team goals, idea exchange, and working as a team.

\section{Peer goal emphasis}

Peers' setting of high standards and encouragement of best effort.

\section{Peer work facilitation}

Peers' help in improving performance, planning, and problem solving.

\section{Performance clarity}

The extent to which the company makes performance expectations clear to employees.

\section{Performance emphasis}

The extent to which the company is demanding of employees, expecting high levels of performance from them and holding them personally accountable for results.

\section{Risk tolerance}

The degree to which employees are encouraged to be aggressive, innovative, and risk-seeking.

\section{Reward system}

The degree to which reward allocations (that is salary increases, promotions) are based on employee performance criteria in contrast to seniority, favouritism, and so on.

\section{Responsibility}

The feeling of being your own boss; not having to double-check all your decisions; when you have a job to do, knowing that it is your job. 


\section{Reward}

The feeling of being rewarded for a job well done; emphasizing positive rewards rather than punishments; the perceived fairness of the pay and promotion policies.

\section{Risk}

The sense of riskiness and challenge in the job and in the organization; is there an emphasis on taking calculated risks, or is playing it safe the best way to operate?

\section{Rituals to support values}

The extent to which there are expressive events, ceremonies or rituals which are designed specifically to reinforce in a powerful and incontrovertible way what the organization's values are.

\section{Rewards and punishments}

The extent to which the organization focusses on positively reinforcing behaviour which supports the organization's objectives as opposed to focussing on negatively punishing behaviour that does not support the organization's objectives.

\section{Social relationships}

Socialising with one's work group and mixing friendships with business, such as: 'Get to know the people in your work group' versus 'Don't bother'.

\section{Strong value systems}

Managers tend not to isolate themselves in analytic ivory towers. They stay close to the key activities in the organization and close to the people, many by practising what has become known as 'management by walking around'. Managers tend to see their role as that of managing the values of their organization by setting and reinforcing its basic philosophy.

\section{Stick to the knitting}

The organization does not seek to become a conglomerate managing a portfolio of businesses to spread its risk and exposure. It stays close to what it knows and does well.

\section{Simple organization structure}

The organization has a simple organization structure and tends to avoid large corporate staff groups.

\section{Structure}

The feeling that employees have about the constraints in the organization, how many rules, regulations, procedures there are; is there an emphasis on 'red tape' and going through channels, or is there a loose and informal atmosphere?

\section{Support}

The perceived helpfulness of the managers and other employees in the group; emphasis on mutual support from above and below.

\section{Standards}

The perceived importance of implicit and explicit goals and performance standards; the emphasis on doing a good job; the challenge represented in personal and group goals.

\section{Supportive rlimate}

The extent to which an emotionally supportive atmosphere prevails in the organization.

\section{Strategic organization focus}

The extent to which there is consensus about goals and objectives, an understanding of and commitment to the mission and purpose of the organization.

\section{Standards and values}

The extent to which there is an understanding and belief in those core values and performance standards that contribute towards organizational success.

\section{Supervisory support}

The supervisor's attentiveness, approachability, and willingness to listen.

\section{Supervisory team building}

The supervisor's emphasis of team goals, idea exchange, and working as a team.

\section{Supervisory goal emphasis}

The supervisor's setting of high standards and encouragement of best effort.

\section{Supervisory work facilitation}

The supervisor's helpfulness in improving performance, planning, and problem solving.

\section{Satisfaction}

Satisfaction with group members, the supervisor, the job itself, the organization, pay, and current and future career progress.

\section{Task .upport}

The information sharing. helping other groups, and concern with efficiency, such as: 'Support the work of other groups' versus 'Put down the work of other groups'.

\section{Task innovation}

Being rewarded for creativity, and doing new things, such as: 'Always try to improve' versus 'Don't rock the boat'.

\section{Top management contact}

The extent to which employees get clear communication and support from upper management. This is an indicator of vertical interdependence.

\section{Team work across boundaries}

The extent to which interdisciplinary teams and the integration of input of everyone in the design and delivery of the product or service to the customer is created.

\section{Training}

The extent to which the organization cares about the orientation of new employees and about meeting training needs.

\section{Teamwork}

The extent to which all employees work together with one another for the good of the organization.

\section{Warmth}

The feeling of general good fellowship that prevails in the work group atmosphere; the emphasis on being well-liked; the prevalence of friendly and informal social groups. 
Appendix 2 Rotated factor pattem of 97 items with 408 respondents

\begin{tabular}{|c|c|c|c|c|c|c|c|c|c|c|c|c|c|c|c|}
\hline $\mathrm{mm}$ & tactor & Dacton & racton & TACTOR & $\underset{s}{\text { nacton }}$ & racton & macton & mactor & racton & $\begin{array}{c}\text { Dacton } \\
11\end{array}$ & $\begin{array}{c}\text { racton } \\
11\end{array}$ & $\begin{array}{c}\text { PACTOR } \\
12\end{array}$ & $\underset{\text { incton }}{\text { is }}$ & $\begin{array}{c}\text { Vactón } \\
14\end{array}$ & $\begin{array}{c}\text { PActon } \\
\text { is }\end{array}$ \\
\hline 103 & 0,0034 & 0,0248 & $0.01 \%$ & 0.1212 & o.0uss & 0,072 & 0.074 & 0,0004 & 0.0660 & 0.1475 & 0.0047 & 0.0023 & $-0,0651$ & 0.0717 & -0.0348 \\
\hline 110 & 0.7902 & 0.0358 & $0.03 n$ & 0,1462 & 0.0019 & 0,0006 & 0,1003 & 0.1141 & 0.0539 & 0,0699 & 0.1344 & $-0,0584$ & 0,0385 & 0.0779 & 0,1170 \\
\hline$*$ & $0.78 \pi$ & 0.124 & Denss & 0.1379 & 0.0736 & c.0304 & 0.1450 & o.osss & 0.1217 & 0.2000 & 0,0107 & 0.0334 & 0,0591 & 0.1482 & 0,0539 \\
\hline c & $0.77 m 1$ & $-0,0017$ & 0.0470 & 0.1114 & 0.1132 & $-0,0204$ & •,ecse & 0.1074 & 0,0058 & 0,0117 & 0.059 & 0,0511 & 0.1334 & 0.0735 & 0,0912 \\
\hline 30 & $\operatorname{ars} x$ & 0.0221 & .0031 & 0.1407 & $-0, \mathbf{M 2 2}$ &,+ 0051 & 0.0322 & Q.621 & 0.0403 & 0,123 & 0.0000 & $-0,0100$ & 0,0420 & 0.0641 & 0,0029 \\
\hline n & 0.7462 & 0.0009 & 0,034 & 0,1504 & $0,03 n$ & 0,0524 & 0.117 & 0.023 & 0.1118 & 0,1009 & 0.0422 & 0,0189 & 0.0404 & 0.1077 & 0,1165 \\
\hline 94 & 0,6735 & 0.0228 & 0,0666 & 0.2002 & 0.1328 & Q.2.13 & 0.160 & 0,000 & 0.141 & 0.1320 & 0,0469 & $\rightarrow, 0424$ & 0,1110 & 0.058 & 0.1147 \\
\hline 106 & 0,0266 & 0.0004 & 0.0741 & $-0,0313$ & 0.0319 & 0,0062 & 0.034 & $-0,0234$ & $0.000 \times$ & $-0,047$ & 0.0004 & -0.0549 & 0.0192 & $-0,0009$ & -0.0743 \\
\hline 76 & 0,0003 & 0.7901 & 0.0712 & 0,0060 & 0,0487 & 0.0793 & 0.0123 & 0.0263 & c.02a1 & 0.1377 & 0.0333 & 0,0099 & 0,0060 & $-0,0000$ & $-0,0173$ \\
\hline 132 & 0.016 & 0.719 & $0.07 \%$ & $0,000 \%$ & $-0,0363$ & 0.0025 & 0.1723 & 0.1204 & 0.0130 & 0.0791 & 0.0997 & 0.0501 & $0.06 \mathrm{~m}$ & 0.0311 & 0.0226 \\
\hline$\pi$ & $-0,0010$ & 0.7122 & -0.0111 & $-0,0054$ & 0,0293 & 0,1962 & 0.104 & 0.0363 & -0.0511 & 0,0971 & $-0,0113$ & 0,0522 & 0.0220 & 0.0970 & 0.0950 \\
\hline 32 & 0.0228 & 0.4563 & 0.0562 & $-0,0046$ & 0.0500 & 0.0632 & 0.0011 & -0.1146 & c.0349 & 0.0000 & $-0,02313$ & $-0,0169$ & 0.0167 & 0.0213 & - a.cout \\
\hline 139 & 0.0309 & 0.6557 & 0.0954 & 0.0663 & $-0,0091$ & 0,2122 & 0.0712 & 0.0863 & 0.037 & 0,0592 & 0,0704 & $-0,0153$ & $-0,0061$ & -0.0031 & 0.1547 \\
\hline$"$ & 0.0358 & $0.65 \mathrm{sen}$ & 0.0151 & $-0,0022$ & 0,0371 & $0.02 n$ & 0.1100 & -0.0593 & 0,422 & 0,0016 & - 0,0016 & 0,0059 & $0.010 \pi$ & 0.0060 & 0.1093 \\
\hline 101 & 0.0563 & 0.6220 & 0.1329 & 0.0194 & $-0.02 \times 3$ & 0.0302 & 0,114 & 0.0350 & 0.1250 & 0.0770 & 0,0307 & 0.0412 & 0.0132 & 0.0439 & 0,1669 \\
\hline los & 0.1173 & 0.5260 & 0,0974 & 0.0873 & 0.2311 & 0,1637 & 0.1106 & 0.0413 & -.0472 & 0.0760 & $-0,0621$ & -0.0136 & 0.0654 & $-0,0158$ & 0,064 \\
\hline 141 & 0,104 & 0.1488 & $0.21 \%$ & 0.0237 & 0,0958 & 0,0303 & $-0,0312$ & 0.0570 & 0.0597 & 0,0016 & 0.0693 & 0.0097 & 0.1232 & 0.0234 & 0,0637 \\
\hline 160 & 0.0767 & 0.0936 & 0.2257 & 0,0139 & $-0,0031$ & 0,0306 & 0.0107 & 0,0565 & $-0,01 \mathrm{~m}$ & 0.1212 & 0.0363 & 0.0400 & 0.0431 & 0.0234 & 0,0499 \\
\hline 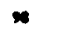 & 0.0230 & 0.0140 & 0.20092 & 0.0106 & 0.00000 & 0,0620 & 0.0384 & 0.0549 & 0.0503 & 0,0701 & 0.0027 & 0.0479 & 0.1231 & 0.0797 & $0,05 M$ \\
\hline 3 &.,- 0713 & 0.0311 & $0.7 m$ & $-0,0023$ & $-0,0333$ & 0,0668 & 0,0059 & 0,0041 & -0.0167 & 0,0973 & 0.0100 & 0,0418 & 0.0479 & -0.0062 & 0.0471 \\
\hline 37 & 0.058 & 0.0915 & 0.7936 & 0.0368 & 0.0200 & -0.0121 & 0.0281 & 0.0093 & 0.0713 & .0933 & -0.0009 & -0.0331 & 0.0634 & 0,00013 & 0,0597 \\
\hline 36 & $-0,0205$ & 0.1499 & 0.6039 & 0.0540 & 0,0043 & 0.067 & 0,0011 & 0,0237 & $-0,0000$ & 0.1673 & 0,0394 & 0.1135 & 0,0403 & -0.0156 & $-0,0399$ \\
\hline 119 & 0.0049 & 0.0395 & $0.54 \mathrm{M}$ & 0.1371 & 0,1327 & 0.1054 & 0,0960 & 0,0009 & $-0,07 \times$ & 0,1222 & 0,014 & 0.0462 & 0.0534 & 0.0927 & 0.037 \\
\hline 123 & 0.1913 & 0.0363 & 0.0112 & $0.7 \mathrm{~m} 2$ & $-0,0169$ & 0,0937 & 0.0335 & 0.1599 & $0.04 \pi$ & 0.0222 & 0,0732 & 0.0193 & 0.0061 & 0,0570 & o.04s3 \\
\hline 46 & 0.1275 & 0.0134 & 0.0493 & 0.7370 & 0.0619 & 0,0003 & 0.1263 & 0.091 & 0,034 & -0.070 & 0,1145 & 0,0763 & 0,0051 & $-0,0 \times 24$ & 0,0051 \\
\hline 125 & 0.1781 & 0.0506 & $0.09 n$ & 0.7337 & 0.0000 & 0.0794 & -0.0017 & 0.0326 & 0.1266 & 0.0522 & 0.000 & 0,0319 & 0.0540 & 0.0532 & 0.0128 \\
\hline 3 & $0.17 n s$ & -0.0168 & -0.0073 & 0,7222 & 0.0659 & 0.0237 & 0.1073 & 0.1627 & 0.0546 & -0.1063 & -0.0114 & 0.0717 & 0.0733 & $0.015 s$ & 0,0764 \\
\hline 143 & 0.1564 & 0.0130 & 0.0632 & 0.7126 & 0.047 & 0,0062 & 0,1132 & 0.0113 & 0.1719 & 0.0721 & 0.1160 & $0.13 \%$ & 0.0467 & 0.1247 & 0.0900 \\
\hline 142 & 0.1607 & 0.0139 & 0.0612 & 0.6003 & 0.0015 & 0,2000 & 0.0343 & 0.1338 & $0.1 \% 2$ & $0,022 \mathrm{~m}$ & 0.0902 & 0,0997 & 0.0061 & 0.0020 & 0.0013 \\
\hline 152 & 0.0330 & 0.0636 & 0.0394 & $0.5 \mathrm{mz}$ & 0.1401 & 0,0147 & 0.0730 & .00424 & 0.1633 & 0.107 & 0,0012 & 0.1070 & 0.1365 & 0.1434 & 0.1194 \\
\hline 164 & 0.1131 & -0.0070 & $-0,00 \mathrm{e}$ & 0.0158 & 0.8274 & 0,1129 & 0.0375 & 0.1336 & 0.0050 & $0.020 \mathrm{~A}$ & 0.0393 & 0.0618 & $-0,0396$ & 0,0971 & 0.1104 \\
\hline 126 & 0,0766 & 0.1160 & 0.0004 & 0.00052 & 0.759 & 0.0468 & 0.0752 & 0,0315 & 0,1316 & 0,0052 & 0.097 & 0.1027 & 0.0054 & 0.1364 & 0,0633 \\
\hline$\pi$ & 0.0320 & 0.159 & 0.0812 & 0.0039 & 0.6795 & 0.1116 & -0.0063 & 0.00100 & $0.12 \mathrm{~s}$ & 0,00032 & 0.0429 & 0.1267 & 0,0665 & 0.1240 & 0.0402 \\
\hline 20 & -0.0226 & $-4,064$ & -0.0301 & $-0,0452$ & 0.0132 & 0.1357 & $-0,0532$ & 0,0091 & 0.1294 & 0,0538 & 0,0791 & $-0,011 \approx$ & $-0,0029$ & 0.0343 & $-0,0073$ \\
\hline 127 & $\rightarrow, 0216$ & 0.1019 & 0.0123 & 0.0030 & 0.6264 & 0.0553 & 0.00000 & 0.0923 & 0.0003 & 0.0756 & 0,1091 & 0.0209 & 0,0517 & 0,1277 & 0,0034 \\
\hline 79 & 0,0987 & $-0,0405$ & $-0,0257$ & $0.07 \mathrm{~m}$ & 0.614 & 0.1370 & 0.0602 & 0.1113 & 0,0227 & 0.8243 & $-0,0291$ & 0,1314 & $-0,0339$ & 0,1200 & 0,1019 \\
\hline 161 & 0.1201 & 0.1114 & 0.1146 & 0,06012 & 0.6038 & 0,0060 & 0.0946 & 0.0982 & 0.1142 & $0,12 \mathrm{M}$ & 0,0079 & 0,0503 & $0,03 \omega$ & 0.1427 & 0,0796 \\
\hline 153 & 0,034 & 0.1160 & -0.0037 & 0,0611 & 0.174 & 0.7579 & 0.0582 & 0.1821 & $-0,0001$ & -0.0731 & 0.0493 & 0,1062 & 0.0213 & 0,0206 & $-0,0512$ \\
\hline 63 & 0.0076 & 0.0736 & $0.04 \%$ & 0,00009 & 0.0993 & 0.7313 & 0.0409 & 0.1427 & 0,00097 & 0,0003 & 0,0948 & 0,037 & 0,1493 & 0,0484 & -0.0470 \\
\hline ss & 0.0662 & 0.1436 & 0.1047 & 0.1416 & 0,0971 & 0,7750 & 0,1223 & 0.1003 & -0.0353 & 0.0797 & 0.0293 & 0.1374 & 0.1063 & 0.0611 & $0.06 \mathrm{sen}$ \\
\hline 136 & $-0,0273$ & 0.146 & 0,0103 & $\overbrace{}^{0.0292}$ & 0.1124 & 0.7212 & $0, \mathbf{M 6 ]}$ & 0,1304 & 0.0606 & 0,0199 & 0.0705 & 0,1583 & 0,0504 & 0,0480 & 0.0097 \\
\hline$\infty$ & 0.0113 & 0.2126 & 0.0475 & 0.0626 & 0.0712 & 0.6947 & 0,0695 & 0.1100 & 0,0540 & 0,0327 & 0.1107 & 0.049 & 0.0502 & 0.1103 & 0.0600 \\
\hline , & 0.00222 & 0.0300 & 0.1222 & 0.0023 & $0,04 \times$ & 0,6409 & 0.107 & 0.0738 & -0.0348 & 0.0070 & 0.0765 & 0.0791 & 0.0509 & 0,0303 & 0,0449 \\
\hline$\omega$ & 0.0609 & 0.1661 & 0.0668 & •.1499 & $0.2 \mathrm{~ms}$ & 0,4425 & $0.12 \pm 0$ & 0.1367 & 0,0794 & 0.2033 & 0,0253 & 0.0629 & 0.1591 & 0.1173 & $-0,0040$ \\
\hline 157 & 0.1262 & $0.112 z$ & 0.057 & 0.0478 & 0,0256 & 0.0019 & 0.7403 & 0.0702 & 0.1311 & 0.1387 & 0.0503 & 0,0024 & 0.0161 & 0,0358 & 0.0687 \\
\hline$\omega$ & 0.2109 & 0,1246 & $0.02 \%$ & 0.0599 & 0.0400 & 0,0536 & 0.6903 & 0.0606 & 0.2062 & 0,0601 & 0.0477 & 0,0267 & 0.0193 & 0.0916 & 0.0637 \\
\hline 146 & $1,0<18$ & 0.1069 & -0.0030 & 0,0458 & $-0,0067$ & 0.0817 & 0.6749 & $0,0 \% 4$ & 0.1221 & 0.1032 & 0.1736 & 0,0550 & 0.0636 & 0.0473 & 0.0146 \\
\hline 122 & 0.1369 & 0,1226 & 0.0435 & 0,0076 & 0.0856 & 0.0607 & 0,6722 & 0,139 & 0.1287 & 0.0505 & 0.1001 & 8.0819 & 0,0539 & 0.1139 & 0.1491 \\
\hline 144 & 0.0682 & 0.0973 & 0.0610 & 0.0048 & 0,012 & $0,000 \mathrm{n}$ & 0.6645 & 0.1259 & 0.1033 & 0,0523 & 0,1790 & 0.0327 & 0,0723 & 0.0393 & 0.1967 \\
\hline
\end{tabular}




\begin{tabular}{|c|c|c|c|c|c|c|c|c|c|c|c|c|c|c|c|}
\hline min & $\begin{array}{c}\text { TACTOR } \\
\text { I }\end{array}$ & $\begin{array}{c}\text { Facton } \\
1\end{array}$ & $\begin{array}{c}\text { racton } \\
\text { i }\end{array}$ & Dactok & $\begin{array}{c}\text { macton } \\
3\end{array}$ & macton & $\begin{array}{c}\text { racton } \\
7\end{array}$ & IActon & racton & macton & II & $\underset{12}{\text { macton }}$ & $\begin{array}{c}\text { II } \\
\text { IS }\end{array}$ & $\underset{\text { in }}{\text { tacton }}$ & $\begin{array}{c}\text { Bacton } \\
\text { is }\end{array}$ \\
\hline $\begin{array}{l}100 \\
16\end{array}$ & $\begin{array}{l}0.0795 \\
0.0166\end{array}$ & $\begin{array}{l}0.1002 \\
0.1117\end{array}$ & $\begin{array}{l}0,0000 \\
-0,0324\end{array}$ & $\begin{array}{l}0.0935 \\
0.0507\end{array}$ & $\begin{array}{l}0.0054 \\
0.0605\end{array}$ & $\begin{array}{l}0,0000 \\
0,0077\end{array}$ & $\begin{array}{l}0.6514 \\
0.6007\end{array}$ & $\begin{array}{l}0.0706 \\
0.1053\end{array}$ & $\begin{array}{l}0.1180 \\
-0.0119\end{array}$ & $\begin{array}{l}0.0528 \\
0.0202\end{array}$ & $\begin{array}{l}0.1314 \\
0.0774\end{array}$ & $\begin{array}{l}0.0504 \\
-0,0742\end{array}$ & $\begin{array}{l}0.0226 \\
-0,02 n\end{array}$ & $\begin{array}{l}0.1400 \\
0.0903\end{array}$ & $\begin{array}{l}0.1191 \\
0.0240\end{array}$ \\
\hline 67 & 0,0357 & $-0,0487$ & 0,0434 & $0.05 n$ & 0.1211 & 0.1451 & 0.1204 & 0.0017 & 0.0148 & 0.0920 & 0,00035 & $-0,02 \times 3$ & 0.0216 & 0.0173 & $0.0 m 0$ \\
\hline 162 & 0.064 & $-0,0316$ & .0.060 & 0.1066 & 0.072 & 0.0675 & .1211 & $0, \pi n$ & $0.113 n$ & 0.030 & 0.1127 & conss & a.cost & ansos & 0,0000 \\
\hline 134 & 0.134 & 0.0610 & 0.1173 & 0.1231 & $0.14 \pi$ & 0.1060 & $0.0 \mathrm{rr}$ & 0.000s & 0,0018 & CDIas" & anzs2 & $0 . \mathrm{mes}$ & 0.072 & 0.1102 & 0.65 \\
\hline 93 & 0,0360 & 0.1146 & $0,0000 \mathrm{~s}$ & 0.137 & 0.1350 & 0.1256 & 0.1237 & 0,6701 & $-0,0030$ & 0.07es & 0,0113 & 0,0261 & 0.1580 & הבנתם & 0.001 \\
\hline 104 & 0.0615 & $-0,0262$ & 0,0219 & 0.100 & $0.1 \mathrm{~ns}$ & 0.1426 & 0.11009 & 0.640 & 0.0002 & a.1326 & a.0200 & 0.0210 &. $.0 m$ & .100 & 0.0030 \\
\hline 62 & 0.0509 & 0.0658 & 0.0003 & 0,0342 & 0.0220 & 0,1058 & 0,0005 & 0.5806 & 0,0543 & 0.0502 & 0.0068 & 0.0390 &,- 0340 & 0.1200 & 0,011 \\
\hline 131 & a.034s & 0,0300 & $-0,0711$ & 0.1119 & $0.100 \mathrm{~N}$ &,+ 0363 & a.mis & $0.00 \times 3$ & 0.6006 & 0.0331 & 0.0.132 & 0.0313 & 0.0687 & omm & 0,0043 \\
\hline 147 & 0,1428 & 0,035 & 0,0611 & 0.1137 & 0.1719 & 0,0512 & 0.007 & -0.0109 & D.coss & 0.0996 & 0,0216 & 0.0220 & $0.07 m$ & 0,0503 & 0.0760 \\
\hline 150 & $0.03 n$ & 0,097 & $-0,0530$ & 0.147 & 0,0001 & $0.05 s 4$ & 200012 & 0.0027 & 0.997 & 0.0154 & D.1 1seck & 0.0622 & e.coen & 0.0030 & 0.0000 \\
\hline 22 & 0.0553 & 0,0324 & 0,0148 & 0,0321 & 0,0370 & $-0,0118$ & 0.1220 & 0.0135 & -.s*s2 & 0.131 & -.,043 & -0.0117 & -.0697 & 0.019 & 0,2407 \\
\hline 154 & 0.1259 & 0,0420 & 0.0776 & 0,069 & 0,1316 & $-0,0416$ & 0.1141 & 0.1295 & 0.5600 & 0.0623 & -0.0130 & 0.1007 & 0.0022 & 0.0746 & $-0.00 \%$ \\
\hline 24 & 0.0656 & $-0,0273$ & 0.0051 & 0.02023 & 0.mps & $-0,0102$ & 0.0706 & -0.0200 & 0.5610 & 0.1336 & 0,0304 & 0.004 & 0,0300 & 0.1116 & OQN27 \\
\hline 9 & 0.0000 & 0,0404 & 0.0862 & 0.0087 & 0.1220 & 0.0904 & 0.2119 & $0.05 n s$ & 0.3974 & $0.1 \% 1$ & $-0,0052$ & $0.07 \mathrm{~ms}$ & 0.0000 & 0.1180 & 0,1921 \\
\hline 169 & 0.1033 & 0.1023 & 0.1816 & 0.0062 & 0.0007 & 0,023 & Q.onss & $0.05 \mathrm{sm}$ & 0.1326 & $0 . m 1$ & 0.00036 & $-0,0239$ & $-0,02 \pi$ & conn & 0.0001 \\
\hline 119 & 0.0098 & 0,0542 & 0,1309 & -0.0052 & $0.00 \mathrm{N2}$ & 0.0767 & 0.1000 & -0.0020 & $-0,0112$ & 0.7433 & 0,0002 & 0.0632 & 0.0601 & 0.0362 & -1.0071 \\
\hline 85 & 0.1234 & 0.1257 & 0,1223 & 0 & 0,079 & 0.1343 & 0,0091 & 0.0062 & 0.1010 & 0.6367 & $-0,0161$ & 0.0543 & 2.054 & 0.100 & e.esse \\
\hline$\pi$ & 0.127 & 0.0434 & 0,0056 & 0,0232 & 0,011 & 0.1231 & 0.0320 & 0.1112 & 0.0925 & 0.6236 & 0,00002 & 0.0515 & 0.0435 & 0.0961 & 0,0291 \\
\hline 47 & 0.1237 & 0,0751 & 0,1659 & -0.0193 & 0,0718 & -0.0713 & 0,0727 & 0.018 & 0.1602 & 0.5907 & $\rightarrow, 0736$ & 0,0013 & -0.01s1 & 0.019 & $\rightarrow, 0563$ \\
\hline 4 & $.13 n$ & a,030s & $-0,0015$ & 0.0007 & $0.13 \%$ & $-0,0235$ & 0.1426 & 0.1226 & 0.1729 & 0.3916 & $0.01 \%$ & 0.0446 & -0.0438 & 0.103 & 0.0004 \\
\hline 121 & 0,050 & $-0,0136$ & $0.01 \mathrm{~m}$ & $0.00 n$ & $0.02 \mathrm{al}$ & 0.0571 & 0.1404 & 0.0070 & 0.0003 & 0.0116 & omon & 0.0271 & $0.11 \mathrm{M}$ & $0.07 n$ & 0.0423 \\
\hline 148 & 0.000 & $-0,005 s$ & 0,0254 & 0.1316 & 0.0013 & 0.1616 & 0.1590 & 0.0036 & 0.0310 & 0.0216 & $0 . \pi 70$ & 0.0183 & 0.1267 & 0.1000 & 0,0556 \\
\hline 7 & 0,1063 & 0.0512 & 0,038 & 0.0770 & 0.0095 & 0.00007 & 0.1460 & 0.0707 & -0.0119 & 0.0091 & 0,7139 & 0.0533 & 0.1691 & anss & 0.1006 \\
\hline $\boldsymbol{n}$ & 0 & 0.0312 & 0.0524 & 0.1301 & 0.1707 & 0.0500 & 0,1425 & $0.2 \times n$ & 0,0 ss & $-0,0329$ & $0.67 \mathrm{ml}$ & 0,037 & 0.2131 & 0.1093 & a.02m \\
\hline 40 & 0.079 & -0.0952 & $0,02 s s$ & 0,1313 & 0,0034 & 0,067 & 0.1763 & $-0,0 \mathrm{~min}$ & 0,0261 & -0.0501 & - .5047 & 0,0233 & 0,0300 & $-0 . \mathrm{men}$ & $0,1 \times 4$ \\
\hline 107 & 0.0001 & $-0,0193$ & -0.0000 & 0.0720 & 0.0516 & 0.134 & -.0131 & $-0,0003$ & 0.0029 & 0.0087 & 0.0200 & 0.8300 & 0.037 & $-0,0<12$ &,+ 0615 \\
\hline 120 & $-0,01 \pi$ & 0.1103 & 0,074 & 0,1116 & $0,05 \mathrm{sen}$ & 0.1027 & $0,00 n n$ & 0.0000 & -0.0185 & 0.1174 & 0,0581 & $0.7 m$ & 0,0004 & 0.0573 & 0,0307 \\
\hline$\leftrightarrow$ & 0,0006 & $-0,00 \mathrm{~m}$ & 0,0650 & $-0,000 x$ & 0.1460 & 0.1435 & 0.0391 & 0.0133 & 0.0003 & 0.0733 & -.027 & 0.7465 & 0.0062 & c.07as & -0.0573 \\
\hline 18 & 0,000 & $-0,00 n$ & 0,0051 & 0.1176 & 0.0300 & 0.1073 & 0.0731 & $0.01 \%$ & 0.1123 & 0.0236 & 0,0103 & $0.730 \%$ & 0.0423 & -0.0761 & -0.0223 \\
\hline 23 & $-0,0707$ & 0,1013 & 0,0 ans & 0.1202 & 0.0032 & 0.047 & 0.0358 & e,0319 & 0.0239 & 0.0001 & 0.0960 & 0.607 & 0.0203 & 0.0530 & 0.1035 \\
\hline 36 & 0.0501 & 0.1157 & 0.0000 & 0,1216 & 0.00133 & 0.1456 & 0.0039 & o.t1es & -0.0239 & -0.0001 & 0.1060 & 0,073 & 0,7000 & a.cesss & 0.072 \\
\hline 167 & 0.0516 & $-0,0079$ & 0.1499 & 0.1076 & $0.01 \%$ & 0,019 & 0.0547 & 0.0501 & 0.0222 & -0.0313 & 0.1946 & $-0,0002$ & 0.7377 & 0.1295 & 0.1252 \\
\hline 4 & a.enss & 0.0536 & 0,0050 & 0.0360 & $-0,0021$ & 0.1000 & 0.0609 & a.0316 & -0.0004 & 0.0311 & 0.017 & $0,05 x$ & a.s26s & o.jem & 0.1033 \\
\hline 34 & 0.149 & 0,0569 & 0.1506 & $0,03 \mathrm{~K}$ & 0.0718 & 0,0667 & 0.0325 & 0.0423 & 0.1141 & 0.0335 & 0.000 & 0.0731 & 0.6226 & 0.2268 & 0.1502 \\
\hline$n$ & 2.0730 & 0.0018 & 0.1900 & 0.1271 & $-0,007 n$ & 0.1418 & 0,0197 & -0.0283 & 0.1418 & -0.011 & 0.1928 & -0.0055 & $0.92 n s$ & 0.1852 & 0.0541 \\
\hline 124 & 0,0003 & 0.0625 & 0,0030 & 0,0001 & 0.1602 & $0,0 \times 1$ & 0.0062 & 0.00472 & 0.0192 & 0.0313 & 0.0022 & $-0,00013$ & 0.1347 & $0 . \omega n$ & Q.110 \\
\hline 9 & 0.123 & 0.01122 & 0,0096 & 0.107 & 0.1769 & 0.0179 & 0,1690 & $0,122 \mathrm{~s}$ & 0.2169 & 0,0238 & 0.0310 & -.ess & 0.127 & 0.6181 & 0.1320 \\
\hline 102 & 0,1221 & $0.007 n$ & 0.0032 & -0.0002 & 0.1428 & 0,0773 & 0.00814 & 0.0213 & 0,1140 & 0.0230 & 0.0292 & 0.0004 & 0.0054 & 0.6135 & -.0011 \\
\hline $\boldsymbol{\mu}$ & 0,054 & 0.0623 & $0.0 \mathrm{N2S}$ & 0.0117 & 0.1256 & 0.0716 & 0.1492 & 0.1361 & 0.114 & 0.0006 & 0.1074 & 0.1103 & 0,0005 & 0.5863 & 0.1169 \\
\hline 114 & 0,0528 & 0.0067 & 0.1418 & 0.1396 & 0.1600 & 0.0001 & 0.1391 & 0.0900 & conss & 0.063 & 0.0421 & 0,0230 & 0,1238 & 0.5443 & 0.148 \\
\hline 149 & 0,0762 & $-0,0107$ & -0.0061 & 0,1010 & $0,0 \mathrm{~mm}$ & 0.0326 & 0.019 & 0.1292 & 0.0241 & 0.1733 & 0.0300 & +.0222 & 0.1313 & 0.3361 & A.coses \\
\hline 23 & Q.00992 & 0.0321 & 0.0750 & 0.1274 & 0.1260 & -0.0156 & 0.1211 & 0.0584 & 0.0328 & 0.0223 & 0,0705 & -0.0223 & 0.027 & 0,0374 & 0.6367 \\
\hline 20 & 0.0593 & 0.1077 & 0.0019 & 0,1434 & 0.0300 & -0.0324 & 0,0299 & 0.0101 & 0.1107 & $-0,0331$ & 0.02187 & •.0329 & 0.1461 & 0,0035 & ossoos \\
\hline 130 & 0.2316 & 0.1797 & 0,0640 & 0,0790 & -0.0007 & $-0,030$ & 0.1933 & $0.130)$ & 0.1673 & 0.1618 & $0.17 \mathrm{~s}$ & -0.0120 & 0.107 & 0.0620 & 0.941 \\
\hline 139 & 0.1649 & 0.1762 & 0.1264 & 0.0961 & 0.0619 & 0,0983 & 0.1460 & 0.1314 & 0.072 & 0.0026 & 0.0003 & 0.0191 & 0.0419 & 0.1295 & D.s1a1 \\
\hline 17 & 0,1213 & 0.0692 & 0.1009 & 0.1401 & 0.1528 & tossil & 0.0040 & $0.13 \times 0$ & 0.0701 & 0.0006 & 0.1601 & $+022 u$ & $0.22 \mathrm{~m}$ & 0.0050 & 0.9129 \\
\hline 41 & 0,0348 & -0.0609 & 0.0316 & 0.0330 & 0.028 & 0.1034 & 0.1400 & -0.0100 & 0.1324 & -0.0217 & 0.0046 & 0.0669 & 0.1726 & 0.1285 & 0.5034 \\
\hline
\end{tabular}




\section{Appendix 3 Questionnaire}

The objective of this survey is to determine how members of the organization in which you work, feel about various organizational processes.

The survey is anonymous. Please do not write your name on the questionnaire. Responses cannot be traced to any individual. The free and frank expression of your own opinion will be most helpful.

There are no right or wrong answers to any of the items in this questionnaire. It is your opinion on each of the statements that matters.

This questionnaire contains a number of statements about the organization in which you work. You are requested to respond to each of the statements by putting a cross in the space which most accurately fits the extent to which you agree that the statement describes the organization in which you work.

After you have read each statement, please decide the degree to which the statement accurately describes your own situation and your own feelings, using the following scale:

1. Completely disagree

2. Mostly disagree

3. Slightly disagree

4. Undecided

5. Slightly agree

6. Mostly agree

7. Completely agree

Exumple:

\begin{tabular}{|l|c|c|c|c|c|c|c|}
\hline & $\begin{array}{c}\text { Completely } \\
\text { disagree }\end{array}$ & $\begin{array}{c}\text { Mostly } \\
\text { disagree }\end{array}$ & $\begin{array}{c}\text { Slightly } \\
\text { disagree }\end{array}$ & $\begin{array}{c}\text { Un- } \\
\text { decided }\end{array}$ & $\begin{array}{c}\text { Slightly } \\
\text { agree }\end{array}$ & $\begin{array}{c}\text { Mostly } \\
\text { agree }\end{array}$ & $\begin{array}{c}\text { Completely } \\
\text { agree }\end{array}$ \\
\cline { 2 - 8 } & 1 & 2 & 3 & 4 & 5 & 6 & 7 \\
\cline { 2 - 7 } $\begin{array}{l}\text { 1. Managers in this organization really care about } \\
\text { employees. }\end{array}$ & & & & & & & \\
\hline
\end{tabular}

If you completely agree with this statement you would put an $\mathrm{x}$ below 7 . If, on the other hand, you slightly disagree with the statement you would put an $\mathrm{x}$ below 3 , and so on.

Please read each of the statements carefully and then put a cross in the space that most accurately describes how you see the situation in your organization.

When you have completed all the items please return the questionnaire in the envelope provided. 


\section{Questionnaire}

\begin{tabular}{|c|c|c|c|c|c|c|c|c|}
\hline & & $\begin{array}{l}\text { Completely } \\
\text { disagree }\end{array}$ & Mostly & $\begin{array}{l}\text { Slightly } \\
\text { disagree }\end{array}$ & Undocided & $\begin{array}{c}\text { Slightly } \\
\text { agree }\end{array}$ & $\begin{array}{l}\text { Mostly } \\
\text { agree }\end{array}$ & $\begin{array}{l}\text { Completely } \\
\text { agree }\end{array}$ \\
\hline & & 1 & 2 & 3 & 4 & 5 & B & 7 \\
\hline 1. & $\begin{array}{l}\text { Employees in this organisation are not aware } \\
\text { of the objectives of the organisation. }\end{array}$ & & & & & & & \\
\hline 2. & $\begin{array}{l}\text { In this organisation there is little emphasis on } \\
\text { doing a good job. }\end{array}$ & & & & & & & \\
\hline 3. & $\begin{array}{l}\text { In this organisation, authority to make } \\
\text { decisions is only in the hands of senior } \\
\text { managers. }\end{array}$ & & & & & & & \\
\hline 4. & $\begin{array}{l}\text { In this organisation decisions have to be } \\
\text { referred upwards all the time. }\end{array}$ & & & & & & & \\
\hline 5. & $\begin{array}{l}\text { In this organisation employees are expected to } \\
\text { contribute towards the achievement of the } \\
\text { organisation's objectives and this is what is } \\
\text { rewarded. }\end{array}$ & & & & & & & \\
\hline 6. & $\begin{array}{l}\text { In this organisation employees are committed } \\
\text { to making the organisation successful. }\end{array}$ & & & & & & & \\
\hline 7. & $\begin{array}{l}\text { This organisation has a high regard for its } \\
\text { employees. }\end{array}$ & & & & & & & \\
\hline 8. & $\begin{array}{l}\text { In this organisation the sharing of information } \\
\text { between departments and work groups is not } \\
\text { encouraged. }\end{array}$ & & & & & & & \\
\hline 9. & $\begin{array}{l}\text { This organisation places a low premium on } \\
\text { high performance. }\end{array}$ & & & & & & & \\
\hline 10. & $\begin{array}{l}\text { Employees in this organisation have the } \\
\text { freedom and independence to do their jobs } \\
\text { effectively. }\end{array}$ & & & & & & & \\
\hline 11. & $\begin{array}{l}\text { This organisation does not treat its employees } \\
\text { as if they are a valued resource. }\end{array}$ & & & & & & & \\
\hline 12. & $\begin{array}{l}\text { This organisation does not reward good } \\
\text { performance. }\end{array}$ & & & & & & & \\
\hline 13. & $\begin{array}{l}\text { In this organisation there are too many rules, } \\
\text { regulations and standard procedures. }\end{array}$ & & & & & & & \\
\hline 14. & $\begin{array}{l}\text { This organisation does not allow itself to get } \\
\text { side-tracked by issues which do not really } \\
\text { matter. }\end{array}$ & & & & & & & \\
\hline 15. & $\begin{array}{l}\text { Employees are not encouraged to reveal any } \\
\text { differences of opinion which they may have } \\
\text { with their bosses. }\end{array}$ & & & & & & & \\
\hline 16. & $\begin{array}{l}\text { in this organisation little emphasis is placed on } \\
\text { performance standards. }\end{array}$ & & & & & & & \\
\hline 17. & $\begin{array}{l}\text { Employees in this organisation have to get } \\
\text { approval from above before they can act. }\end{array}$ & & & & & & & \\
\hline 18. & $\begin{array}{l}\text { Managers in this organisation provide clear } \\
\text { communication, assistance and support to } \\
\text { their subordinates. }\end{array}$ & & & & & & & \\
\hline 19. & This organisation really values its customers. & & & & & & & \\
\hline 20. & $\begin{array}{l}\text { In this organisation employees have to } \\
\text { observe many rules and regulations in doing }\end{array}$ & & & & & & & \\
\hline
\end{tabular}




\begin{tabular}{|c|c|c|c|c|c|c|c|c|}
\hline & & $\begin{array}{c}\text { Completely } \\
\text { disagree }\end{array}$ & Mostly & $\begin{array}{l}\text { Slightly } \\
\text { disagree }\end{array}$ & Undecided & $\begin{array}{l}\text { Slightly } \\
\text { agreo }\end{array}$ & $\begin{array}{l}\text { Mostly } \\
\text { agree }\end{array}$ & $\begin{array}{c}\text { Completely } \\
\text { agree }\end{array}$ \\
\hline & & 1 & 2 & 3 & 4 & 5 & 6 & 7 \\
\hline 21. & $\begin{array}{l}\text { In this organisation employees have to follow } \\
\text { many standard procedures in doing their jobs. }\end{array}$ & & & & & & & \\
\hline 22. & $\begin{array}{l}\text { In this organisation there is a strong emphasis } \\
\text { on the customer. }\end{array}$ & & & & & & & \\
\hline 23. & $\begin{array}{l}\text { In this organisation there is an informal } \\
\text { atmosphere which helps employees to get the } \\
\text { job done. }\end{array}$ & & & & & & & \\
\hline 24. & $\begin{array}{l}\text { Differing views are encouraged in this } \\
\text { organisation. }\end{array}$ & & & & & & & \\
\hline 25. & $\begin{array}{l}\text { Employees in this organisation are sufficiently } \\
\text { aware of the organisation's goals. }\end{array}$ & & & & & & & \\
\hline 26. & $\begin{array}{l}\text { Employees in this organisation have } \\
\text { confidence and trust in each other. }\end{array}$ & & & & & & & \\
\hline 27. & $\begin{array}{l}\text { Employees in this organisation are consulted } \\
\text { in respect of decisions regarding what the } \\
\text { organisation plans to do. }\end{array}$ & & & & & & & \\
\hline 28. & $\begin{array}{l}\text { This organisation does not really value its } \\
\text { employees. }\end{array}$ & & & & & & & \\
\hline 29. & $\begin{array}{l}\text { In this organisation emphasis is placed on } \\
\text { rewarding employees for success rather than } \\
\text { punishing them for failure. }\end{array}$ & & & & & & & \\
\hline 30. & $\begin{array}{l}\text { In this organisation support across work group } \\
\text { and departmental boundaries is strongly } \\
\text { encouraged. }\end{array}$ & & & & & & & \\
\hline 31. & $\begin{array}{l}\text { Employees in this organisation are genuinely } \\
\text { encouraged to participate in broad } \\
\text { organisational policy matters. }\end{array}$ & & & & & & & \\
\hline 32. & $\begin{array}{l}\text { In this organisation bosses do not like to hear } \\
\text { the other side of the story. }\end{array}$ & & & & & & & \\
\hline 33. & $\begin{array}{l}\text { The different sub-units in this organisation are } \\
\text { not encouraged to work together effectively } \\
\text { toward the achievement of the organisation's } \\
\text { goals. }\end{array}$ & & & & & & & \\
\hline 34. & $\begin{array}{l}\text { In this organisation employees from different } \\
\text { departments are encouraged to work together } \\
\text { for the overall good of the organisation. }\end{array}$ & & & & & & & \\
\hline 35. & $\begin{array}{l}\text { Employees in this organisation do not } \\
\text { understand what contribution is expected from } \\
\text { them. }\end{array}$ & & & & & & & \\
\hline 36. & $\begin{array}{l}\text { This organisation listens to the views of its } \\
\text { employees. }\end{array}$ & & & & & & & \\
\hline 37. & $\begin{array}{l}\text { This organisation is definitely not customer- } \\
\text { oriented. }\end{array}$ & & & & & & & \\
\hline 38. & $\begin{array}{l}\text { This organisation rewards employees on the } \\
\text { basis of performance. }\end{array}$ & & & & & & & \\
\hline 39 . & $\begin{array}{l}\text { This organisation has a poor understanding of } \\
\text { the things that really matter. }\end{array}$ & & & & & & & \\
\hline 40. & $\begin{array}{l}\text { There is nothing holding this organisation } \\
\text { together and binding its members to one } \\
\text { another. }\end{array}$ & & & & & & & \\
\hline
\end{tabular}


41. In this organisation there is no emphasis on individual initiative.

\begin{tabular}{|c|c|c|c|c|c|c|c|c|}
\hline & & $\begin{array}{c}\text { Completely } \\
\text { disagree }\end{array}$ & $\begin{array}{l}\text { Mostly } \\
\text { dizagroe }\end{array}$ & $\begin{array}{l}\text { Slightly } \\
\text { disagree }\end{array}$ & Undecided & $\begin{array}{l}\text { Slightly } \\
\text { agree }\end{array}$ & $\begin{array}{l}\text { Mostly } \\
\text { agree }\end{array}$ & $\begin{array}{l}\text { Completely } \\
\text { agree }\end{array}$ \\
\hline & & 1 & 2 & 3 & 4 & 5 & 6 & 7 \\
\hline 42. & $\begin{array}{l}\text { Employees in this organisation do not know } \\
\text { what is expected of them in their jobs. }\end{array}$ & & & & & & & \\
\hline 43. & $\begin{array}{l}\text { In this organisation employees are } \\
\text { encouraged to be creative and innovative. }\end{array}$ & & & & & & & \\
\hline 44. & $\begin{array}{l}\text { This organisation has strong values which are } \\
\text { widely shared by its members. }\end{array}$ & & & & & & & \\
\hline 45. & $\begin{array}{l}\text { Managers in this organisation seldom } \\
\text { communicate to employees what the } \\
\text { organisation's values and philosophies are. }\end{array}$ & & & & & & & \\
\hline 46. & $\begin{array}{l}\text { In this organisation inter-departmental co- } \\
\text { operation is very strongly encouraged. }\end{array}$ & & & & & & & \\
\hline 47. & $\begin{array}{l}\text { This organisation really takes its customers } \\
\text { seriously and listens to them. }\end{array}$ & & & & & & & \\
\hline 48. & $\begin{array}{l}\text { This organisation sets no performance } \\
\text { standards for its employees. }\end{array}$ & & & & & & & \\
\hline 49. & $\begin{array}{l}\text { Few of the activities in this organisation centre } \\
\text { around things that are really vital to its } \\
\text { success. }\end{array}$ & & & & & & & \\
\hline 50. & $\begin{array}{l}\text { This organisation does not allow employees to } \\
\text { participate in the decision-making process. }\end{array}$ & & & & & & & \\
\hline 51. & $\begin{array}{l}\text { In this organisation senior management is } \\
\text { helpful and supportive when required. }\end{array}$ & & & & & & & \\
\hline 52. & $\begin{array}{l}\text { In this organisation not following the chain of } \\
\text { command to get a job done, is frowned upon. }\end{array}$ & & & & & & & \\
\hline 53. & $\begin{array}{l}\text { In this organisation there is an emphasis on } \\
\text { giving the customer the best quality and } \\
\text { service. }\end{array}$ & & & & & & & \\
\hline 54. & $\begin{array}{l}\text { In this organisation managers go out of their } \\
\text { way to ensure that different departments } \\
\text { operate in a co-ordinated way. }\end{array}$ & & & & & & & \\
\hline 55. & $\begin{array}{l}\text { In this organisation employees are empowered } \\
\text { to make appropriate decisions and they do not } \\
\text { have to refer everything up the line. }\end{array}$ & & & & & & & \\
\hline 56. & $\begin{array}{l}\text { This organisation tends to deal with } \\
\text { differences of opinion by ignoring them or by } \\
\text { pretending that they do not exist. }\end{array}$ & & & & & & & \\
\hline 57. & $\begin{array}{l}\text { This organisation treats its employees as } \\
\text { though they have nothing to contribute } \\
\text { towards the organisation's performance. }\end{array}$ & & & & & & & \\
\hline 58. & $\begin{array}{l}\text { This organisation concentrates on those } \\
\text { activities which form part of the fundamentals } \\
\text { of the business. }\end{array}$ & & & & & & & \\
\hline 59. & $\begin{array}{l}\text { In this organisation little emphasis is placed on } \\
\text { the achievement of goals. }\end{array}$ & & & & & & & \\
\hline
\end{tabular}




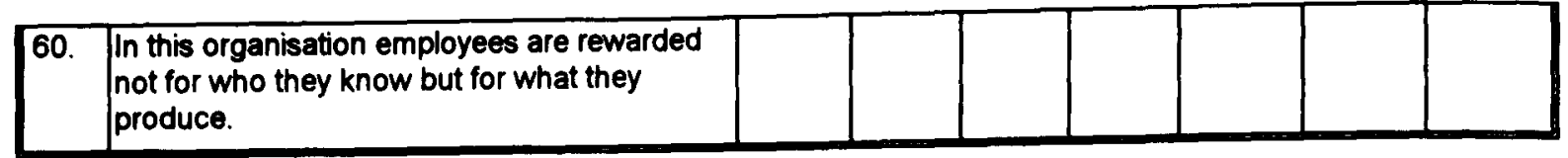

\begin{tabular}{|c|c|c|c|c|c|c|c|c|}
\hline & & $\begin{array}{c}\text { Completely } \\
\text { disagree }\end{array}$ & $\begin{array}{l}\text { Mostly } \\
\text { disagree }\end{array}$ & $\begin{array}{l}\text { Slightly } \\
\text { disagree }\end{array}$ & & $\begin{array}{l}\text { Slightly } \\
\text { agroe }\end{array}$ & $\begin{array}{c}\text { Mostly } \\
\text { agree }\end{array}$ & $\begin{array}{c}\text { Completely } \\
\text { agree }\end{array}$ \\
\hline & & 1 & 2 & 3 & 4 & & - & 7 \\
\hline 61. & $\begin{array}{l}\text { Employees in this organisation are not } \\
\text { constrained by rules, regulations, policies and } \\
\text { procedures in doing their jobs. }\end{array}$ & & & & & & & \\
\hline 62. & $\begin{array}{l}\text { Employees in this organisation have very little } \\
\text { say in their own work goals. }\end{array}$ & & & & & & & \\
\hline 63. & $\begin{array}{l}\text { Everything that employees do in this } \\
\text { organisation is directed at accomplishing the } \\
\text { organisation's goals. }\end{array}$ & & & & & & & \\
\hline 64. & $\begin{array}{l}\text { Managers in this organisation seldom do } \\
\text { anything which shows employees what is } \\
\text { important for the organisation's long term } \\
\text { success. }\end{array}$ & & & & & & & \\
\hline 65. & $\begin{array}{l}\text { Employees in this organisation have a say in } \\
\text { the organisation's work methods. }\end{array}$ & & & & & & & \\
\hline 66. & $\begin{array}{l}\text { In this organisation employees are always } \\
\text { encouraged to search for better ways of } \\
\text { getting the job done. }\end{array}$ & & & & & & & \\
\hline 67. & $\begin{array}{l}\text { This organisation has no idea what it needs to } \\
\text { do exceptionally well in order to survive and } \\
\text { prosper. }\end{array}$ & & & & & & & \\
\hline 68. & $\begin{array}{l}\text { This is not an innovative organisation and new } \\
\text { ideas are generally discouraged. }\end{array}$ & & & & & & & \\
\hline 69. & $\begin{array}{l}\text { The people in this organisation are not } \\
\text { interested in hearing views that do not agree } \\
\text { with their views. }\end{array}$ & & & & & & & \\
\hline 70. & $\begin{array}{l}\text { Creativity is definitely not encouraged in this } \\
\text { organisation. }\end{array}$ & & & & & & & \\
\hline 71. & $\begin{array}{l}\text { This organisation treats employees like good } \\
\text { performers rather than poor performers. }\end{array}$ & & & & & & & \\
\hline 72. & $\begin{array}{l}\text { This organisation views its employees as } \\
\text { important contributors to the organisation's } \\
\text { success. }\end{array}$ & & & & & & & \\
\hline 73. & $\begin{array}{l}\text { In this organisation there is a norm to maintain } \\
\text { progress and strive towards excellence. }\end{array}$ & & & & & & & \\
\hline 74. & $\begin{array}{l}\text { This organisation consistently makes } \\
\text { employees aware of how they are expected to } \\
\text { behave at work. }\end{array}$ & & & & & & & \\
\hline 75. & $\begin{array}{l}\text { In this organisation there is a low level of trust } \\
\text { in and openness with bosses. }\end{array}$ & & & & & & & \\
\hline 76. & $\begin{array}{l}\text { The goals which are set in this organisation } \\
\text { are tough but realistic. }\end{array}$ & & & & & & & \\
\hline 77. & $\begin{array}{l}\text { This organisation does not allow employees to } \\
\text { concentrate their efforts on the right activities. }\end{array}$ & & & & & & & \\
\hline 78. & Employees do not experience a sense of & & & & & & & \\
\hline
\end{tabular}




\begin{tabular}{|c|c|c|c|c|c|c|c|c|}
\hline & belonging to this organisation. & & & & & & & \\
\hline 79. & $\begin{array}{l}\text { In this organisation there are many standard } \\
\text { procedures which employees have to adhere } \\
\text { to at all times. }\end{array}$ & & & & & & & \\
\hline & & $\begin{array}{l}\text { Completely } \\
\text { disagroe }\end{array}$ & $\begin{array}{l}\text { Mostly } \\
\text { disagree }\end{array}$ & $\begin{array}{l}\text { Slightly } \\
\text { disagree }\end{array}$ & Undecided & $\begin{array}{l}\text { Stightly } \\
\text { agroe }\end{array}$ & $\begin{array}{l}\text { Mostly } \\
\text { agree }\end{array}$ & $\begin{array}{c}\text { Completely } \\
\text { agree }\end{array}$ \\
\hline & & 1 & 2 & 3 & 4 & 5 & 8 & 7 \\
\hline 80. & $\begin{array}{l}\text { In this organisation communication flows freety } \\
\text { and accurately throughout the organisation - } \\
\text { upward, downward and laterally. }\end{array}$ & & & & & & & \\
\hline 81. & $\begin{array}{l}\text { Employees in this organisation cannot rely on } \\
\text { management support when needed. }\end{array}$ & & & & & & & \\
\hline 82. & $\begin{array}{l}\text { There is an air of openness and trust in this } \\
\text { organisation. }\end{array}$ & & & & & & & \\
\hline 83. & $\begin{array}{l}\text { Employees in this organisation have a clear } \\
\text { understanding of what its values and } \\
\text { philosophies are. }\end{array}$ & & & & & & & \\
\hline 84. & $\begin{array}{l}\text { This organisation has a participative } \\
\text { management style. }\end{array}$ & & & & & & & \\
\hline 85. & $\begin{array}{l}\text { In this organisation goals are not clearly } \\
\text { defined. }\end{array}$ & & & & & & & \\
\hline 86. & $\begin{array}{l}\text { Employees in this organisation assist each } \\
\text { other because they share a high degree of } \\
\text { commitment to making the organisation } \\
\text { successful. }\end{array}$ & & & & & & & 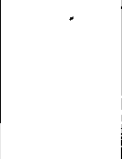 \\
\hline 87. & $\begin{array}{l}\text { In this organisation employees are involved in } \\
\text { decisions which directly impact on their work. }\end{array}$ & & & & & & & \\
\hline 88. & $\begin{array}{l}\text { Employees in this organisation do not identify } \\
\text { with the organisation. }\end{array}$ & & & & & & & \\
\hline 89. & $\begin{array}{l}\text { This is a focused organisation which knows } \\
\text { how to get the basic things right. }\end{array}$ & & & & & & & \\
\hline 90. & $\begin{array}{l}\text { Employees in this organisation are } \\
\text { encouraged to use their own initiative in doing } \\
\text { their jobs. }\end{array}$ & & & & & & & \\
\hline 91. & $\begin{array}{l}\text { Employees in this organisation understand the } \\
\text { objectives of the organisation. }\end{array}$ & & & & & & & \\
\hline 92. & $\begin{array}{l}\text { This organisation does not encourage its } \\
\text { employees to identify with each other and the } \\
\text { organisation. }\end{array}$ & & & & & & & \\
\hline 93. & $\begin{array}{l}\text { Differences of opinion are welcomed in this } \\
\text { organisation. }\end{array}$ & & & & & & & \\
\hline 94. & $\begin{array}{l}\text { In this organisation employees are supervised } \\
\text { very closely. }\end{array}$ & & & & & & & \\
\hline 95. & $\begin{array}{l}\text { Employees in this organisation are not allowed } \\
\text { to get on with their jobs because they have to } \\
\text { double check all decisions with their bosses. }\end{array}$ & & & & & & & \\
\hline 96. & $\begin{array}{l}\text { Employees in this organisation share a high } \\
\text { degree of commitment to make the } \\
\text { organisation successful. }\end{array}$ & & & & & & & \\
\hline 97. & $\begin{array}{l}\text { In this organisation there is a clear link } \\
\text { between reward and performance. }\end{array}$ & & & & & & & \\
\hline
\end{tabular}


Appendix 4 Key to questionnaire

\begin{tabular}{|c|c|c|}
\hline CULTURE DIMENSION & QUESTIONNAIRE ITEM & NEGATIVE/POSITIVE \\
\hline Conflict resolution & $\begin{array}{l}93 \\
69 \\
56 \\
15 \\
82 \\
32 \\
24\end{array}$ & $\begin{array}{l}\mathrm{P} \\
\mathrm{N} \\
\mathrm{N} \\
\mathrm{N} \\
\mathrm{P} \\
\mathrm{N} \\
\mathrm{P}\end{array}$ \\
\hline Culture management & $\begin{array}{l}44 \\
83 \\
40 \\
74 \\
45 \\
64\end{array}$ & $\begin{array}{l}\mathbf{P} \\
\mathbf{P} \\
\mathbf{N} \\
\mathbf{P} \\
\mathbf{N} \\
\mathbf{N}\end{array}$ \\
\hline Customer orientation & $\begin{array}{l}22 \\
37 \\
53 \\
47 \\
19 \\
\end{array}$ & $\begin{array}{l}\text { P } \\
\text { N } \\
\text { P } \\
\text { P } \\
\text { P }\end{array}$ \\
\hline Disposition toward change & $\begin{array}{l}66 \\
43 \\
41 \\
70 \\
68 \\
\end{array}$ & $\begin{array}{l}\mathrm{P} \\
\mathrm{P} \\
\mathrm{N} \\
\mathrm{N} \\
\mathrm{N}\end{array}$ \\
\hline Employee participation & $\begin{array}{l}31 \\
84 \\
27 \\
50 \\
65 \\
87 \\
62 \\
\end{array}$ & $\begin{array}{l}\mathbf{P} \\
\mathbf{P} \\
\mathbf{P} \\
\mathbf{N} \\
\mathbf{P} \\
\mathbf{P} \\
\mathbf{N}\end{array}$ \\
\hline Goal clarity & $\begin{array}{r}25 \\
91 \\
35 \\
42 \\
85 \\
63 \\
1 \\
\end{array}$ & $\begin{array}{l}\mathbf{P} \\
\mathbf{P} \\
\mathbf{N} \\
\mathbf{N} \\
\mathbf{N} \\
\mathbf{P} \\
\mathbf{N}\end{array}$ \\
\hline Human resources orientation & $\begin{array}{r}28 \\
7 \\
11 \\
57 \\
72\end{array}$ & $\begin{array}{l}\mathbf{N} \\
\mathbf{P} \\
\mathbf{N} \\
\mathbf{N} \\
\mathbf{P}\end{array}$ \\
\hline
\end{tabular}

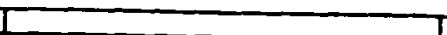




\begin{tabular}{|c|c|c|}
\hline CULTURE DIMENSION & QUESTIONNAIRE ITEM & NEGATIVE/POSITIVE \\
\hline Identification with the organisation & $\begin{array}{r}86 \\
88 \\
96 \\
78 \\
92 \\
26 \\
6 \\
\end{array}$ & $\begin{array}{l}\mathrm{P} \\
\mathrm{N} \\
\mathrm{P} \\
\mathrm{N} \\
\mathrm{N} \\
\mathrm{P} \\
\mathrm{P} \\
\end{array}$ \\
\hline Locus of authority & $\begin{array}{r}3 \\
95 \\
55 \\
90 \\
10 \\
4\end{array}$ & $\begin{array}{l}\mathrm{N} \\
\mathrm{N} \\
\mathrm{P} \\
\mathrm{P} \\
\mathrm{P} \\
\mathrm{N}\end{array}$ \\
\hline Management style & $\begin{array}{l}75 \\
81 \\
80 \\
18 \\
51 \\
36\end{array}$ & $\begin{array}{l}N \\
N \\
P \\
P \\
P \\
P\end{array}$ \\
\hline Organisation focus & $\begin{array}{l}77 \\
89 \\
58 \\
14 \\
67 \\
49 \\
39\end{array}$ & $\begin{array}{l}\mathrm{N} \\
\mathrm{P} \\
\mathrm{P} \\
\mathrm{P} \\
\mathrm{N} \\
\mathrm{N} \\
\mathrm{N}\end{array}$ \\
\hline Organisation integration & $\begin{array}{r}34 \\
30 \\
54 \\
8 \\
46 \\
33 \\
\end{array}$ & $\begin{array}{l}\mathrm{P} \\
\mathrm{P} \\
\mathrm{P} \\
\mathrm{N} \\
\mathrm{P} \\
\mathrm{N}\end{array}$ \\
\hline Performance orientation & $\begin{array}{r}2 \\
73 \\
59 \\
76 \\
48 \\
9 \\
16 \\
\end{array}$ & $\begin{array}{l}\mathrm{N} \\
\mathrm{P} \\
\mathrm{N} \\
\mathrm{P} \\
\mathrm{N} \\
\mathrm{N} \\
\mathrm{N}\end{array}$ \\
\hline Reward orientation & $\begin{array}{r}38 \\
5 \\
71 \\
97 \\
60 \\
12 \\
29\end{array}$ & $\begin{array}{l}\mathrm{P} \\
\mathrm{P} \\
\mathrm{P} \\
\mathrm{P} \\
\mathrm{P} \\
\mathrm{N} \\
\mathrm{P}\end{array}$ \\
\hline
\end{tabular}




\begin{tabular}{|c|l|l|}
\hline CULTURE DIMENSION & QUESTIONNAIRE ITEM & NEGATIVE/POSITIVE \\
\hline & 17 & $\mathrm{~N}$ \\
& 21 & $\mathrm{~N}$ \\
& 52 & $\mathrm{~N}$ \\
Task structure & 20 & $\mathrm{~N}$ \\
& 94 & $\mathrm{~N}$ \\
& 79 & $\mathrm{~N}$ \\
& 61 & $\mathrm{P}$ \\
& 13 & $\mathrm{~N}$ \\
\hline
\end{tabular}

